\title{
The Revision of American State Constitutions: Legislative Power, Popular Sovereignty, and Constitutional Change
}

This Comment argues that reyision of state constitutions ought to proceed slowly to promote stability in constitutional law. Such stability is valuable because it fosters popular sovereignty, pluralism, and limited constitutional government. This Comment thus criticizes judicial decisions upholding constitutional revision by extratextual means and recent attempts to replace traditional revision procedures with more expedient provisions. The older, more cumbersome procedures are preferable because they preserve the capacity of elections to measure the will of the popular sovereign, both by promoting voter competence and by limiting the likelihood of constitutional revisions that promote narrow interests at the expense of the people as a whole.

\section{INTRODUCTION}

The Supreme Court's recent retreat from the Warren Court's expansive interpretations of individual constitutional rights, particularly in the area of criminal procedure, ${ }^{1}$ has led some state courts to maintain prior levels of constitutional protection by interpreting their state constitutions to require those protections. ${ }^{2}$ Justices Brennan and Stevens have explic-

1. Examples of the recent retreat from criminal procedure protections under the federal constitution include: United States v. Leon, 468 U.S. 897 (1984) (creating "good faith" exception to the exclusionary rule under the fourth amendment); Massachusetts v. Sheppard, 468 U.S. 981 (1984) (same); New York v. Quarles, 467 U.S. 649 (1984) (creating public safety exception to the fifth amendment privilege against self-incrimination); Illinois v. Gates, 462 U.S. 213 (1983) (adopting "totality of the circumstances" test to determine probable cause sufficient for a search warrant).

2. For example, a Supreme Court decision granting police considerable freedom to search impounded automobiles despite the constraints of the fourth amendment led the South Dakota Supreme Court on remand to declare the "inventory search" a violation of that state's constitution. Compare South Dakota v. Opperman, 428 U.S. 364 (1976) with State v. Opperman, 247 N.W.2d 673 (S.D. 1976).

Similarly, the Washington Supreme Court rejected the United States Supreme Court's rationale for replacing the two-prong Aguilar-Spinelli test of probable cause with the "totality of the circumstances test." Compare State v. Jackson, 102 Wash. 2d 432, 688 P.2d 136 (1984) (requiring both the "veracity" and "basis of knowledge" prongs to be satisfied for a showing of probable cause) with Illinois v. Gates, 462 U.S. 213 (1983) (allowing a strong showing on either the "veracity" or the "basis of knowledge" prong to compensate for a deficient showing on the other).

State constitutional jurisprudence has provided greater protection of individual rights than does the federal constitution in areas other than criminal procedure. In Robins v. PruneYard Shopping Center, 23 Cal. 3d 899, 592 P.2d 341, 153 Cal. Rptr. 854 (1979), aff'd, 447 U.S. 74 (1980), the California Supreme Court held that California's constitutional guarantee of free expression protects 
itly encouraged this practice. ${ }^{3}$

The principle of federalism is often invoked to justify this new attention to state constitutional law, which is aptly called the;"New Federalism." Indeed, state protection of individual rights beyond the minimum provided by the federal constitution can serve the peculiar needs and values of a particular state. Florida, for example, may not wish to provide greater protection against unreasonable government searches and seizures than does federal constitutional law, ${ }^{4}$ but other states may. California may wish to articulate a right of privacy, ${ }^{5}$ but other states may not. In short, state constitutions can strengthen federalism by allowing the states to articulate, and live by, standards that suit their different needs. ${ }^{6}$

Recent Supreme Court decisions regarding the tenth amendment and the role of federalism in our constitutional system have also focused attention on the role of state constitutional law in articulating and protecting basic rights. In National League of Cities v. Usery, ${ }^{7}$ the Supreme Court struck down the apphication of the minimum wage provisions of the Fair Labor Standards Act ${ }^{8}$ to the states, holding that the courts could enforce the tenth amendment's limitation of federal power on behalf of the states. This doctrine would have provided a judicial guarantee of a role for the states, and for state constitutional law, in our political system. Usery was rejected by a five-to-four Court in Garcia v. San Antonio

reasonably exercised speech in a privately owned shopping mall despite the objections of the owner. PruneYard rejected the U.S. Supreme Court's analysis of the same issue in Lloyd Corp. v. Tanner, 407 U.S. 551 (1972).

The Supreme Court has responded to these state court developments by requiring state courts to make clear that their decisions rest on "independent state grounds" strictly defined, rather than on disfavored interpretations of federal rights. See Michigan v. Long, 463 U.S. 1032 (1983).

3. See Michigan v. Moseley, 423 U.S. 96, $111-21$ (1975) (Brennan, J., dissenting); Brennan, State Constitutions and the Protection of Individual Rights, 90 HARV. L. REv. 489 (1977); South Dakota v. Neville, 459 U.S. 553, 566-71 (1983) (Stevens, J., dissenting). For a forceful restatement of Justice Brennan's views on this subject, see Brennan, The Bill of Rights and the States, 61 N.Y.U. L. REV. 535 (1986).

4. In November 1982, Florida voters ratified a constitutional amendment which provided that the state constitutional right against unreasonable searches and seizures "shall be construed in conformity with the 4th amendment to the United States Constitution, as interpreted by the United States Supreme Court." FLA. CoNST. art. I, $\$ 12$ (1968, amended 1982). The provision also requires that Florida courts apply the federal standards under the exclusionary rule. Id.

5. In November 1972, California voters amended the state constitution to provide explicit protection of the right to privacy. CAL. CoNST. art. I, $\$ 1$ (1849, amended 1972, repealed and reenacted 1974). No parallel provision exists in the federal constitution. Instead, privacy rights have been found by implication. See, e.g., Griswold v. Conneeticut, 381 U.S. 479, 484 (1965).

6. A similar argument that state constitutional law strengthens federalism has been made by Oregon Supreme Court Justice Hans A. Linde. See Linde, E Pluribus-Constitutional Theory and State Courts, 18 GA. L. REv. 165, 193-200 (1984).

7. 426 U.S. 833 (1976).

8. The Fair Labor Standard Aet of 1938, 28 U.S.C. $\$ \S 201-219$ (1940). 
Metropolitan Transit Authority, ${ }^{9}$ but as Justice Rehnquist stated in dissent, the belief that the Supreme Court should enforce the principle of federalism on behalf of the states may "in time again command the support of a majority of th[e] Court."10

The "new federalism" and the debate about judicial enforcement of the tenth amendment have excited new interest in state constitutional law, ${ }^{11}$ raising anew the question of whether state courts can provide meaningful protection of individual rights. In fact, the new federalism debate rests on the assumption that state courts can do so. However, because state courts are more subject to majoritarian pressure than are their federal counterparts, ${ }^{12}$ they may be unable to protect the rights of minorities. The capacity of state courts to protect individuals from the majoritarian process is also called into doubt by the ease with which many state constitutions may be changed. Simply put, constitutional law cannot protect individuals from the 1najority if the inajority can (and does) refashion constitutional law at will. This Comment addresses the relationships among the inethods of changing state constitutions, the preservation of individual rights, and majoritarian control of government.

Part I of this Cominent discusses the necessity of state constitutional change and surveys the various constitutional processes by which it may be accomplished. Parts II and III consider extratextual revision: Part II describes and criticizes the rationales typically advanced in support of such revision, and Part III outlines the argument against it. Finally, Part IV argues that procedurally arduous ineans of achieving constitutional change are preferable not only because they represent an accepted norm, but also because they foster societal consensus on basic values, promote constitutional stability, and linit majoritarianism.

9. 469 U.S. 528 (1985).

10. Id. at 580 (Rehnquist, J., dissenting).

11. Interest in state constitutional law has been expressed by students, scholars, and judges. See, e.g., Comment, Individual Rights and State Constitutional Interpretations: Putting First Things First, 37 BAyLOR L. REv. 493 (1985) (criticizing Texas Court of Criminal Appeals for failing to provide greater protection to criminal defendants than available under the federal constitution as interpreted by the Burger Court); Symposium: The Emergence of State Constitutional Law, 63 TEX. L. REv. 959 (1985); Mosk, State Constitutionalism: Both Liberal and Conservative, 63 TEx. L. REv. 1081 (1985) (arguing that state constitutional law could satisfy liberals by increasing protection of individual rights and satisfy conservatives by defending federalism).

12. See, generally, Fischer, Ballot Propositions: The Challenge of Direct Democracy to State Constitutional Jurisprudence, 11 HASTINGS CoNST. L.Q. 43 (1983) (discussing majoritarian pressure on state judges but arguing that state constitutional law has successfully resisted such pressure). 
Constitutional Change

\section{A. The Necessity of Constitutional Change}

Although constitutional principles typically are thought to have lasting significance, and are therefore designed to be changed only infrequently, a constitution must change in response to changing social and political realities. Although an extreme case, Rhode Island's Dorr Rebellion powerfully demonstrates this point.

In 1841, Rhode Island was governed under the Colonial Charter of 1663. The Charter restricted suffrage to a small class of landowners, apportioned seats in the legislature in a manner that failed to reflect the population shifts of almost two centuries, and concentrated political power in the legislature at the expense of the executive and judicial branches. ${ }^{13}$ The refusal of the state's political leadership and its small electorate to allow constitutional change provoked an attempted reform under the "right of revolution" stated in the Declaration of Independence. ${ }^{14}$ The Rhode Island Suffrage Association called a constitutional convention and drafted a constitution that was approved in an election open to the state's 25,000 white, male voters by a margin of some 14,000 to $52 .{ }^{15}$

The election resulted in two vying state governments: the government established by this so-called "People's Constitution," headed by Thomas W. Dorr, ${ }^{16}$ and the Charter government. The Dorrites attempted to seize the armory at Providence, but Charter government troops won the resulting skirmish. ${ }^{17}$ Thereafter, the Charter government drafted a new constitution that broadened suffrage somewhat and lessened the inequities of legislative apportionment. That constitution was ratified in an election open to all native-born, white, male residents; it received the support of some 7,000 voters. $^{18}$

The United States Supreme Court refused to intervene in the contest between the Charterites and the Dorrites, labeling the conflict a "political question" best resolved by the executive and legislative branches of the federal government. ${ }^{19}$ Thus, the Charter government remained in power because the Dorrites had not succeeded by force or by law.

13. See P. Coleman, The Transformation of Rhode ISLAND, 1790-1860, at 254-62 (1963).

14. See infra note 83; see also Coleman, supra note 13, at 270.

15. See Coleman, supra note 13, at 274 . The estimate of the state's white, male population is provided by Coleman. Id. at 272 .

16. Id. at $282-83$.

17. Id. at 283 .

18. Id. at 284-85.

19. See Luther v. Borden, 48 U.S. (7 How.) 1 (1849). 
This incident demonstrates not only that there must be some means of constitutional change short of violent rebellion, but also that violence may be the only method by which the right of revolution reserved by the Declaration of Independence may be exercised. The People's Constitution had been supported by a majority of the state's male residents ${ }^{20}$ but did not find support in the law-notwithstanding the right to revolution. The Charterite constitution received the support of only half as many Rhode Island voters ${ }^{21}$ but nevertheless became the organic law of that state. $^{22}$ The issue was decided by force of arms rather than by a choice of the majority of the people of the state.

\section{B. The Process of Constitutional Change}

The constitutions of America's fifty states provide a variety of means for their own amendment and revision. These include provisions allowing changes to be proposed by the legislature, ${ }^{23}$ by initiative petition, ${ }^{24}$ by an elected constitutional convention, ${ }^{25}$ and, in Florida, by an

20. Coleman, supra note 13 , at 274 .

21. Id.

22. The term "organic law," as used in this Comment, is synonymous with "constitution."

23. The following provisions authorize the legislative proposal of constitutional amendments and revisions:

Ala. Const. art. XVIII, $\S \S 284,287$; AlaSKa ConST. art. XIII, $\S 1$; AR12. ConsT. art. XXI, $\S 1$; ARK. Const. art. XIX, § 22; CAL. ConsT. art. XVIII, $\S \S 1,4$; Colo. Const. art. XIX, $\S 2$; ConN. CONST. art. XII; DEL. CONST. art. XVI, § 1; FLA. CONST. art. XI, §§ 1, 5; GA. ConST. art. X, § 1, paras. 1-3; HAw. ConST. art. XVII, $\S \S 1,3$; IDAho ConST. art. XX, $\S 1$; ILI. ConsT. art. XIV, $\S 2$; IND. ConsT. art. XVI, $\S 1$; Iowa ConST. art. X, $\S 1$; KAN. ConsT. art. XIV, $\S 1$; KY. ConsT. $\S 256$; LA. Const. art. XIII, $\S 1$; ME. ConST. art. X, $\S 4$; MD. ConST. art. XIV, $\S 1$; MASS. ConST. amendments art. XLVIII, part IV, $\S \S 1-5$, part V, $\S \S 1,2$; Mich. CoNST. art. XII, $\S 1 ;$ MiNN. Const. art. IX, $\S 1$; Miss. CoNST. art. XV, $\S 273$; Mo. CoNST. art. XII, $\S \S 2(a), 2(b)$; MoNT. CONST. art. XIV, § 8; NEB. CoNST. art. XVI, § 1; NEV. CoNST. art. XVI, § 1; N.H. ConsT. part 2, art. 100, $\S$ a; N.J. CoNST. art. IX, $\S \S 1,6$; N.M. CoNST. art. XIX, $\S 1 ;$ N.Y. ConsT. art. XIX, $\S 1$; N.C. CONST. art. XIII, $\S 4$; N.D. CoNST. art. IV, $\S 45$; OHIo CONST. art. XVI, $\S 1$; OKLA. ConST. art. XXIV, § 1; OR. CoNST. art. IV, $\S 1$, art. XVII, $\S \S 1,2$; PA. ConsT. art. XI, $\S 1$; R.I. ConsT. amendment XLII, $\S 1$; S.C. CoNST. art. XVI, § 1; S.D. ConsT. art. XXIII, $\$ \S 1,3$; TENN. ConsT. art. XI, § 3; TEX. CONST. art. XVII, § 1; UTAH CONST. art. XXIII, § 1; VT. CONST. ch. II, § 72; VA. CoNST. art XII, $\S 1$; WASH. CONST. art. XXIII, $\S 1$; W. VA. art. XIV, $\S 2$; WIS. ConST. XII, $\S 1$; WYO. CONST. XX, $\S 1$.

24. The following provisions authorize the initiative proposal of constitutional amendments or revisions:

ARIZ. Const. art. XXI, $\S 1$; ARK. Const. amendment VII; CAL. Const. art. II, $\$ \S 8,10$, art. XVIII, $\S 3$; Colo. Const. art. V, § 1; FLA. ConsT. art. XI, §§ 3, 5; ILL. Const. art. XIV, $\S 3$; ME. Const. art. IV, part $3, \S 18$; MD. ConsT. art. XVI, $\S \S 1-4$; MASS. ConST. amendment LXXXI; amendment XLVIII, part III, § 2, part IV, §§ 1-5; MICH. CoNST. art. XII, § 2; Mo. CoNST. art. III,

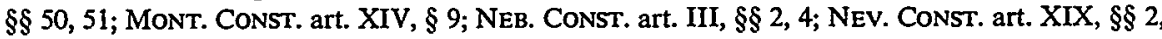
4; N.D. Const. art. III, §§ 1-10; OHIo ConST. art. II, §§ 1(a), 1(b); OKLA. ConsT. art. V, §§ 2, 3; OR. CONST. art. IV, §§ 2-4; S.D. CONST. art. XXIII, §§ 1, 3.

25. The following provisions authorize a constitutional convention to be called to propose constitutional amendments and revisions:

AlA. Const. art. XVIII, § 286; ALASKa CONST. art. XIII, §§ 2-4; ARIZ. ConsT. art. XXI, § 2; CAl. Const. art. XVIII, $\S \S 2,4$; Colo. Const. art. XIX, $\S 1$; ConN. Const. art. XIII, $\S \S 1-4$; 
appointed constitutional revision commission. ${ }^{26}$ Each constitution provides at least one procedure for change.

Many constitutions provide both an "amendment" and a "revision" procedure. The term "amendment" typically refers to changes to one or a few provisions, usually related to a single subject. The term "revision," on the other hand, refers to more pervasive changes, ranging from the drafting of an entirely new document to changes that alter multiple provisions and touch upon multiple subjects. The distinction, of course, is a matter of degree rather than of kind; the result in either case is the adoption of new constitutional language.

The existence of both amendment and revision provisions has prompted some courts to place a substantive limit on amendment proposals, called the "nonrevision" requirement. ${ }^{27}$ This limit is designed to distinguish by scope and subject matter those changes that can be achieved by the less cumbersome amendment process from those that can be achieved solely by revision procedures.

The legislature in each of the fifty states may propose an amendment, either by a specified supermajority of a single legislature or by simple majorities of each of two successive legislatures. ${ }^{28}$ In every state but Delaware, an amendment proposed by the legislature becomes law only when ratified by the electorate. ${ }^{29}$ Typically, electoral ratification is also required for amendments proposed by initiative petition, ${ }^{30}$ constitutional

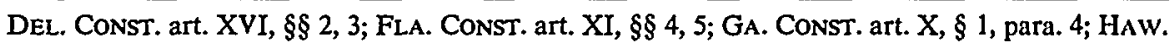
Const. art. XVII, $\S 2$; IDAHo Const. art. XX, $\S \S 3$, 4; ILL. ConsT. art. XIV, $\S 1$; IowA ConsT. art. X, § 3; KAN. Const. art. XIV, § 2; KY. Const. § 258; LA. ConsT. art. XIII, § 2; ME. ConsT. art. IV, part 3d, § 15; MD. Const. art. XIV, § 2; MICH. ConsT. art. XII, § 3; MINN. ConST. art. IX, $\S \S 2$, 3; Mo. ConsT. art. XII, § 3(a); MoNT. ConsT. art. XIV, §§ 1-4, 7; NEB. ConsT. art XVI, $\S 2$; NEV. ConsT. art. XVI, § 2; N.H. CoNST. part 2, art. 100, § c; N.M. CoNST. art. XIX, § 2; N.Y. ConST. art. XIX, § 2; N.C. ConsT. art. XIII, §§ 1, 3; N.D. ConST. art. III, §§ 1, 4-5, 9; Оноо ConsT. art. XVI, $\S \S 2$, 3; OKLA. ConsT. art. XXIV, § 2; R.I. ConST. amend. XLII, § 2; S.C. ConST. art. XVI, § 3; S.D. CoNsT. art. XXIII, §§ 2, 3; TENN. ConsT. art XI, § 3; TEX. CoNST. art. XVII, § 2; UTAH CONST. art. XXIII, §§ 2, 3; VA. CoNST. art. XII, § 2; WASH. ConST. art. XXI1I, $\S \S 2,3$; W. VA. ConST. art. XIV, § 1; WIS. CONST. art. XII, § 2; WYO. ConST. art. XX, §§ 3, 4.

26. FLA. ConST. art. XI, $\S 2$. It is also common for state legislatures and governors to appoint constitutional revision commissions to assist them in carrying out their constitutional responsibilities regarding amendment and revision. See, e.g., THE CounCIL of STATE GovernMeNTS, THE Book OF THE STATES 6-7, $21-22$ (1986 ed.). An extensive bibliography on methods of state constitutional change is provided by Colantuono, Pathfinder: Methods of State Constitutional Revision, 7 LEGAL REFERENCE SERVICES Q. 45 (1987).

27. The leading case articulating the nonrevision requirement is McFadden v. Jordan, $32 \mathrm{Cal}$. 2d 330, 196 P.2d 787 (1948), discussed infra, text accompanying notes 138-53.

28. See sources cited supra note 23 .

29. See sources cited supra note 23. The Delawvare Constitution imposes no requirement of electoral ratification. An amendment proposed by a two-thirds majority of each chamber of the legislature becomes law when ratified by the same majority of the next elected legislature. DEL.. CONST. art. XVI, $\S 1$.

30. See sources cited supra note 24. 
convention, ${ }^{31}$ or constitutional revision commission. ${ }^{32}$

Although six states allow a revision to be proposed by the legislature, ${ }^{33}$ a majority of states require a constitutional convention to revise their constitutions. Though procedures vary from state to state, ${ }^{34}$ the following steps must be taken in most states for a convention to effect constitutional change: (1) the question of whether a convention should be called is presented to the electorate, usually by a specified supermajority of the legislature; ${ }^{35}(2)$ if the proposal is approved, the voters elect a convention; ${ }^{36}$ (3) the convention, which may meet for several months, must approve any proposals; and finally, (4) the voters must ratify the suggested changes. ${ }^{37}$ This process is time consuming, expensive, and frequently fails to achieve constitutional change. ${ }^{38}$

It might appear obvious that the only means by which a constitution can be amended or revised are those provided by the document itself. ${ }^{39}$ However, efforts have been made to achieve constitutional change by different and simpler means. These efforts have included attempts to con-

31. See sources cited supra note 25 .

32. Fla. CONST. art. XI, $\S 2$.

33. CAL. ConST. art. XVIII, $\S \S 1,4$ (constitution adopted 1879); FLA. ConsT. art. XI, $\S \S 1,5$ (constitution adopted 1968); GA. CoNST. art. X, $\S \S 1,2$ (constitution adopted 1976); HAw. CoNST. art. XVIII, $\S \S 1,3$ (constitution adopted 1978); N.C. CoNST. art. XIII, $\S 4$ (constitution adopted 1970); OR.CoNST. art. XVII, $\S 2$ (constitution adopted 1859). Note that four of these six constitutions were adopted in the past twenty years, reflecting a modern trend toward simplifying the processes of constitutional change. See infra text accompanying notes 176-81.

34. Explicit provisions for calling a constitutional convention are found in 41 state constitutions. See sources cited supra note 25 . Other states have held conventions following court decisions finding implied legislative power to call a convention. See, e.g., In re Opinion to the Governor, 55 R.I. 56, 178 A. 433 (1935) (advisory opinion implying legislative authority to call a convention); see also, Opinion of the Justices, 60 Mass. (6 Cush.) 573 (1833) (advisory opinion finding no constitutional authority to call a convention, but suggesting that the legislature or the people might call a convention as an extra-constitutional matter).

35. See sources cited supra note 25 . Some constitutions allow the question to be placed on the ballot by initiative. FLA. CONST. art. XI, $\S 4$; MONT. CONST. art. XIV, $\S 2$; N.D. CONST. art. III, $\S \S 1,4,9$. Others require the question to be placed on the ballot periodically. ALASKA CoNST. art. XIII, § 3; CONN. CONST. art. XIII, § 2; HAW. ConsT. art. XVII, § 2; ILl. CONST. art. XIV, § 1; Iowa Const. art. X, § 3; MD. ConsT. art. XIV, § 2; Mich. ConsT. art. XII, $\S 3$; Mo. Const. art. XII, § 3(a); MoNT. CONST. art. XIV, § 3; N.H. ConST. part 2, art. 100, § b; N.Y. ConST. art. XIX, $\S 2$; OHIO CONST. art. XVI, § 3; OKLA CONST. art. XXIV, § 2; R.I. CONST. amendment XLII, § 2.

36. See sources cited supra note 25 .

37. Although some constitutions require ratification of convention proposals, see sources cited supra note 25 , other states have imposed this requirement by the express or implied terms of the convention call. See, e.g., Erwin v. Nolan, 280 Mo. 401, 217 S.W. 837 (1920) (implied requirement); Wells v. Bain, $75 \mathrm{~Pa} .39$ (1973) (express requirement). Courts in other states have imposed popular ratification as a condition of the implied constitutional power to call a convention. See, e.g., In re Opinion to the Governor, 55 R.I. 56, 178 A. 433 (1935).

38. For a discussion of Virginia's recent successful constitutional revision, and of the failure of efforts in other states, see Howard, Constitutional Revision: Virginia and the Nation, 9 U. RICH. L. REv. 1 (1974).

39. Two state constitutions expressly so provide. Mo. CONST. art. XII, § 1; N.C. CoNST. art. XIII, § 2. 
vene a constitutional convention in the absence of a constitutional provision for doing so, ${ }^{40}$ to completely revise a constitution by a series of legislatively proposed amendments, ${ }^{41}$ and to propose a new constitution by initiative. ${ }^{42}$

Some courts have found an unstated legislative power to call a convention..$^{43}$ Otherwise, few courts have upheld attempts to achieve constitutional change by "extratextual" means-that is, by means other than those provided in the document itself. ${ }^{44}$ It is perhaps surprising that any court would allow constitutional amendment or revision by such means. Yet the courts of at least three states-Georgia, Idaho, and Kentuckyhave done so. ${ }^{45}$ Those courts upheld attempts to seek electoral ratification of constitutions drafted by legislatures without explicit authority to do so. The courts reasoned that the people, as popular sovereign, could give such a proposal constitutional force by adopting it at the polls. ${ }^{46}$

Although this legislative circumvention of the convention process apparently has been sanctioned by only these three courts, ${ }^{47}$ efforts to evade arduous revision procedures are likely to arise in many jurisdictions. Many state constitutions provide only cumbersome means of con-

40. See sources cited supra note 34 .

41. See, e.g., Opinion of the Justices, 264 A.2d 342 (Del. 1970) (advisory opinion allowing proposal of a series of amendments to revise the constitution without calling a convention, but requiring that no proposed amendment be of such scope as to itself accomplish a revision); RiveraCruz v. Gray, 104 So. 2d 501 (Fla. 1958) (invalidating 14 proposed amendments which would have revised entire constitution as violative of the nonrevision requirement).

The current constitution of Florida, the Revised Constitution of 1968, was adopted as a series of three amendments proposed by the legislature. See Sturm, The Procedure of State Constitutional Change-With Special Emphasis on the South and Florida, 5 FLA. ST. U.L. REV. 569, 592 (1977).

42. The Oregon Supreme Court invalidated such an attempt in Holmes v. Appling, 237 Or. 546, 392 P.2d 636 (1964).

43. See sources cited supra note 34 .

44. I am aware of only three decisions allowing extratextual revision. See infra note 45 .

The phrase "constitutional change" as used in this Comment refers to the formal amendment or revision of a constitutional text. It does not include the more common process of constitutional change by judicial interpretation.

45. Wheeler v. Board of Trustees, $200 \mathrm{Ga}$. 323, 37 S.E.2d 322 (1946); Smith v. Cenarrusa, 93 Idaho 818, 475 P.2d 11 (1970); Gatewood v. Matthews, 403 S.W.2d 716 (Ky. 1966); see also Staples v. Gilmer, 183 Va. 613, 629, 33 S.E.2d 49, 56 (1945) (dicta suggest that revision of state constitution through amendment procedures may be permissible). Because the Idaho decision relies heavily on the Georgia and Kentucky precedents and provides little original analysis, it is not discussed in this Comment. The Virginia opinion deals with the call of a limited convention. The court concluded that a convention can be restricted by the terms of the call to the consideration of specified amendments. The court considered the problem of revision by amendment procedures only in dicta, and supports its analysis with an historical argument similar to that made by the Georgia and Kentucky courts. It is not discussed in this Comment because, to the extent that it is relevant, its analysis duplicates that of the opinions discussed.

46. Wheeler v. Board of Trustees, $200 \mathrm{Ga}$. 323, 37 S.E.2d 322 (1946); Smith v. Cenarrusa, 93 Idaho 818, 475 P.2d 11 (1970); Gatewood v. Matthews, 403 S.W.2d 716 (Ky. 1966). These decisions and their rationales are discussed more fully infra. See text accompanying notes 52-126.

47. See supra note 45 . 
stitutional amendment and revision, ${ }^{48}$ and attempts to circumvent these provisions may well recur. In addition, efforts to amend constitutions to establish relatively simple procedures for constitutional change are likely to arise in some of these states. ${ }^{49}$ Although litigation of extratextual revision is uncommon, the design of new constitutions is not. The revision of a state constitution occurs somewhere in the United States almost every year, ${ }^{50}$ and the use of the constitutional mitiative and of other forms of direct democracy is common. ${ }^{51}$ Those who would amend or evade cuinbersome revision provisions inust respond to the arguments in favor of such provisions presented here. We will turn first, however, to the rationale offered to support extratextual revision.

II

\section{The Rationale for EXTRateXtual Revision}

American history provides many examples of constitutional change by novel and questionable means. Foremost is the American Revolution itself. The revolutionary principles of the Declaration of Independence ${ }^{52}$ and the crafting of the American Constitution by a convention with no authority to do $\mathrm{so}^{53}$ demonstrate the historical role of the right of revolution in the American pohitical system. State constitutional history also provides examples of novel or questionable means of constitutional change.

The Florida Revised Constitution of 1968 was adopted as a series of three legislatively proposed amendments following the refusal of the Florida Supreme Court to allow revision by a series of fourteen amendments, each of which provided that it would have no effect unless all

48. See supra text accompanying notes 23-38.

49. Such attempts have been successful in recent years. See supra notes 24-25, 32-33; see infra text accompanying notes $176-81$.

50. In the 1984-85 biennium, for example, constitutional change was underway in Mississippi, New Hampshire, Rhode Island, and Utah. Council of STATE Governments, supra note 26, at 21-22. Each of the 25 earlier editions of THE BOOK OF THE STATES contains a chapter on state constitutions. Together these detail state constitutional change over the past 50 years.

51. See generally Referendums: A Comparative Study of Practice and Theory (D. Butler and A. Ranney eds. 1978) [hereinafter REFERENDuMS].

52. The right of revolution reserved by the Declaration of Independence was cited by both the Wheeler and Gatewood courts. See text accompanying notes 81-83, 117-22. Whether Thomas Jefferson or the signers of the Declaration intended to create a popular right to change the form of government in the absence of tyranny and oppression such as that alleged of King George III is apparently an open question. See O. Vossier, JEFFERSON AND THE AMERICAN REvolutionaRY IDEAL 89-97 (C. Philippon \& B. Wishy trans. 1980) (arguing that modern conceptions of the right of revolution derive from Jefferson's experiences with the French Revolution of 1789 and that the original purpose of the Declaration was to assert legal rights denied the American colonies by the king).

53. This historical precedent was cited by the Georgia Supreme Court in Wheeler v. Board of Trustees, $200 \mathrm{Ga} .323,332-33,37$ S.E.2d 322, 328 (1946). 
fourteen were approved. ${ }^{54}$ The convention that drafted the Kentucky Constitution of 1891 altered it in both form and substance following its electoral ratification, yet did not submit the changes to the voters for their approval. ${ }^{55}$ The Minnesota Constitution is actually two constitutions. This odd state of affairs resulted because the constitutional convention called by the territorial government sat in partisan caucuses and produced two similar, but not identical, proposals. Both proposals were presented for ratification in a single ballot question, and both were approved. $^{56}$ Despite this history, however, few state courts have approved legislative attempts to achieve constitutional change by extratextual means. ${ }^{57}$

The few courts and commentators that have supported extratextual revision have offered two rationales: popular sovereignty and necessity. The popular sovereignty rationale argues that the people possess the inherent right to change their constitution by whatever means they choose. The necessity argument holds that extratextual revision is required by the obsolescence of the revision procedures provided in the constitutional text. This Part examines in turn the decisions of the two courts that offered the popular sovereignty rationale and goes on to consider briefly the necessity rationale.

\section{A. The Popular Sovereignty Rationale}

\section{The Georgia Decision}

In 1946, the Georgia Supreme Court decided Wheeler v. Board of Trustees, the leading case allowing constitutional change by extratextual means. ${ }^{58}$ In 1945, the Georgia General Assembly had adopted a resolution proposing "one single amendment" to the Constitution of 1877 that

54. Sturm, supra note 41, at 592; see also Rivera-Cruz v. Gray, 104 So. 2d 501 (Fla. 1958) (invalidating as violating the nonrevision requirement 14 proposed amendments which would have revised the entire state constitution).

55. 2 Columbia University, Legislative Drafting and Research Fund, Constitutions of THE UNITED STATES: NATION AND State, Editor's Notes to Kentucky Constitution (1974) [hereinafter CONSTITUTIONS OF THE UNITED STATES].

56. 3 Constitutions of THE UNITEd StATES, supra note 55, Editor's Notes to Minnesota Constitution; see also W. ANDERSON \& A. LOBB, A History OF THE CONSTITUTION OF Minnesota 87-114 (1921); J. Jameson, A Treatise on Constitutional Conventions 274 (Chicago 1887 \& photo reprint 1972).

57. But see sources cited supra note 45. The examples cited in the text, it should be noted, involved constitutional conventions in two instances and revision through successive amendments in the third. Because the latter revision complied with the text of the existing constitution, it was not an extratextual revision. The analysis provided by this Comment may suggest that the convention examples were invalid exercises of power, but the argument here is limited to examples of extratextual revision by legislatures. Note that the current Minnesota and Kentucky constitutions are valid in the view of their respective state courts.

58. $200 \mathrm{Ga} .323,37$ S.E.2d 322 (1946). 
would create "the revised Constitution of Georgia."59 A 23-member commission appointed by the governor and other state officials drafted the document in the place of an elected convention. The legislature chose this procedure in order to overcome the opposition of rural legislators who feared that a convention would reapportion the state legislature and eliminate the overrepresentation of rural areas. ${ }^{60}$ Governor Ellis Arnall, an ex officio member of the commission, apparently exerted a great deal of influence over its deliberations. ${ }^{61}$ When the commission divided equally on a proposal to eliminate the constitutional prohibition of a second successive term for a governor, Arnall provided the tie-breaking vote to eliminate the provision. ${ }^{62}$ The legislature reversed that decision, ${ }^{63}$ and amended the commission's proposal extensively before presenting it to the voters. ${ }^{64}$

The proposed constitution differed from the Constitution of 1877 in a variety of ways. It omitted any reference to primary elections in an apparent attempt to avoid the rule of Smith v. Allwright. ${ }^{65}$ In Allwright, the U.S. Supreme Court had found that the exclusion of black voters from primary elections in Texas violated the equal protection clause of the fourteenth amendment. ${ }^{66}$ The proposed constitution also increased the legislature's per diem compensation, eliminated a ceiling on its clerical expenses, and granted it the power to change salaries for all elected officials of the state. ${ }^{67}$ The new document estabhished the office of lieutenant governor. It also changed the structure of the state supreme court, replacing the existing two divisions of three judges with a single court of seven members. ${ }^{68}$ Finally, the proposal raised ceilings established for municipal borrowing and granted the General Assembly considerable new authority over county and municipal government. ${ }^{69}$

The resolution placing the draft on the ballot purported to comply with the amendment provisions of the 1877 constitution, ${ }^{70}$ particularly

59. Proposed Amendment to the Constitution of 1877, approved March 9, 1945, tit. 1, no. 34, 1945 Ga. Laws 8; Wheeler, 200 Ga. at 329-30, 37 S.E.2d at 327.

60. See Saye, Georgia's Proposed New Constitution, 39 AM. Pol. ScI. Rev. 459, 459-60 (1945).

61. Id. at 460 .

62. Id. at 461 .

63. Id.

64. The General Assembly lengthened the proposal from 87 to 92 pages, and, in Professor Saye's words, the result was a document "abounding in statutory and non-essential provisions." Id. at 461 .

65. 321 U.S. 649 (1944).

66. Saye, supra notc 60 , at 462 . In Allwright, the Supreme Court cited Texas statutes regulating primary elections as evidence of state action sufficient to support an equal protection attack on the white primary. 321 U.S. at 653 n.6, 662-64.

67. Saye, supra note 60 , at $462 \&$ n. 10 .

68. Id. at 462 .

69. Id. at 463 .

70. GA. CONST. of 1877 , art. $13, \S 1$, para. 1 ; Wheeler, $200 \mathrm{Ga}$ at 329,37 S.E.2d at 327 . 
article 13 , section 1 , paragraph 1 , which allowed amendments to be proposed by a two-thirds majority of the legislature and ratified by the electorate. ${ }^{71}$ Paragraph 2 of that section permitted revision by a convention called by a two-thirds majority of the legislature. ${ }^{72}$ The 1945 proposal was approved by two-thirds of each chamber of the General Assembly and ratified by a substantial electoral majority. ${ }^{73}$ The Governor then proclaimed the new constitution to be in force. ${ }^{74}$

Almost immediately, critics attacked the new constitution in the Georgia courts. ${ }^{75}$ The Georgia Supreme Court unanimously upheld the new constitution. ${ }^{76}$ The court began by admitting that although the document had been proposed and ratified according to the amendment procedures of the 1877 constitution, it was not actually an amendment to that constitution. It was instead a "completely revised or new constitu-

71. GA. Const. of 1877 , art. $13, \S 1$, para 1 . This provision states:

Any amendment, or amendments, to this Constitution may be proposed in the Senate or House of Representatives and if the same shall be agreed to by two-thirds of the members elected to each of the two houses, such proposed amendments shall be entered on their journals, with the yeas and nays taken thereon. And the General Assembly shall cause such amendment, or amendments, to be published in one or more newspapers in each Congressional District, for two months previous to the time of holding the next general election, and shall also provide for a submission of such proposed amendment or amendments, to the people at said next general election, and if the people shall ratify such amendment or amendments, by a majority of the electors qualified to vote for members of the General Assembly, voting thereon, such amendment or amendments, shall become a part of this Constitution. When more than one amendment is submitted at the same time, they shall be so submitted as to enable the electors to vote on each amendment separately.

See also Wheeler, $200 \mathrm{Ga}$. at 329, 37 S.E.2d at 327.

72. GA. CoNST. of 1877 , art. $13, \S 1$, para. 2. That provision states:

No Convention of the people shall be called by the General Assembly to revise, amend, or change this constitution, unless by the concurrence of two-thirds of all the members of each house of the General Assembly. The representation in said convention shall be based on population as near as practicable.

See also Wheeler, $200 \mathrm{Ga}$. at 330, 37 S.E.2d at 327.

73. Wheeler, $200 \mathrm{Ga}$. at $329-30,37 \mathrm{~S}$.E.2d at 327 . The resolution was approved by margins of $180-3$ in the House of Representatives, $38-9$ in the Senate, and $60,065-34,417$ at the polls. Id. at 334 35, 37 S.E.2d at 329.

74. Id. at 335,37 S.E.2d at 329.

75. The case arose when a taxpayer challenged a bond issue of the Fargo Consolidated School District which had been approved at an election held nineteen days prior to the proclamation of the new constitution. Id. at 323-24, 37 S.E.2d at 324. The district demurred on several grounds, and argued that the new constitution was void and that its limitations on school district borrowing powers were of no effect. Id. at 324-25, 37 S.E.2d at 324. The trial court upheld the new constitution but validated the bond issue on other grounds. Both parties appealed. Id. at 325-26, 37 S.E.2d at 325 .

76. Id. at 336-37, 27 S.E.2d at 330. Although the new constitution also raised the salary of the justices, they did not recuse themselves, holding that the doctrine of necessity required them to hear the case because no other tribunal could be "legally constituted" to do so. Id. at 328,37 S.E.2d at 326. Justice Candler, the newly appointed seventh justice, did recuse himself because his participation would presume the validity of the challenged constitution. Id. Justice Head declined to recuse himself although he had been a member of the commission which had drafted the new document and had, as attorney general, given formal opinions upholding the validity of the revision procedure; the court concurred in his refusal. Id. at $328-29,37$ S.E.2d at 326. 
tion ... the Constitution of 1945."77 The new constitution derived no authority from the feigned compliance with the amendment provision of the old constitution. Neither did it draw force from the actions of the legislature, which had no power to make organic law other than that explicitly granted it by the Constitution of $1877 .{ }^{78}$

In the court's view, the Constitution of 1945 had the force of law because it had been ratified by the voters: "When the people adopt a completely revised or new constitution, the framing or submission of the instrument is not what gives it binding force and effect. The fiat of the people, and only the fiat of the people, can breathe life into a constitution."79 The court observed that the U.S. Constitution had been drafted by a convention called solely to propose amendments to the Articles of Confederation. Nevertheless, it had acquired the force of law by popular ratification. Therefore, the court argued, the vote of the people of Georgia could cure the defects in the preparation of the Constitution of $1945 .^{80}$

The court also relied on article 1, section 5, paragraph 1 of the 1877 constitution, which stated: "The people of this State have the inherent, sole and exclusive right of regulating their internal government, and the police thereof, and of altering and abohshing their Constitution whenever it may be necessary to their safety and happiness."81 Using this language, the court argued that while the legislature might be limited to its expressly delegated powers in inatters of consitutional revision, the power of the people was not so limited by the 1877 constitution. ${ }^{82}$

Despite its reliance on language patterned upon the right to revolution of the Declaration of Independence, ${ }^{83}$ the Georgia court called the

77. Id. at 330,37 S.E. $2 \mathrm{~d}$ at 327 .

78. Id. at $332-33,37$ S.E. $2 \mathrm{~d}$ at 328 .

79. Id. at 333,37 S.E. $2 \mathrm{~d}$ at $328-29$.

80. Id. at $332-33,37$ S.E. $2 \mathrm{~d}$ at 328 .

81. Id. at 333,37 S.E. $2 \mathrm{~d}$ at 329 .

82. Id. at $333-34,37$ S.E. 2 d at 329 . The court might have noted that Georgia history also provides support for extratextual revision: the Georgia Constitution of 1789 was adopted without awaiting petitions from a majority of the counties as required by the 1777 constitution. See Stubbs, Constitution-Making in Georgia, 6 GA. B.J. 207, 208-09 (1944).

83. The provision echoes the following language of the Declaration of Independencc:

We hold these truths to be self-evident, that all men are created equal, that they are endowed by their Creator with certain unalienable Rights, that among these are Life, Liberty and the pursuit of Happiness. That to secure these rights, Governments are instituted among Men, deriving their just powers from the consent of the governed, That whenever any Form of Government becomes destructive of these ends, it is the Right of the People to alter or to abolish it, and to institute new Government, laying its foundation on such principles and organizing its powers in such form, as to them shall seem most likely to effect their Safety and Happiness.

The Declaration of Independence para. 2, sentences 1-2 (U.S. 1776). For a discussion of the philosophical underpinnings of the right to revolution, see 2 Q. SKINNER, THE FOUNDATIONS OF MODERN Political Thought 338-48 (1978). See also supra note 52 and accompanying text. 
adoption of the new constitution "legal." It offered this test of legality:

If a constitution is to be a legal one, as distinguished from a revolutionary constitution, it must be adopted by the people by a compliance with the legal machinery in operation at the time of its adoption in order to obtain a legal expression of the will of the people. ${ }^{84}$

So, while the people are not bound by the terms of a constitution, their acts are revolutionary, rather than legal, if they do not comply with the extant "legal machinery." 85

The court held that this "machinery" did not include the amendment and revision provisions of the Constitution of 1877 , but did include the state's elections statutes. It stated: "Under our system of government the method of expressing the will of the people is by voting in a legally held election."86 Further, for the submission of a ballot question to the voters to be "legal," the proposal must receive the two-thirds majority of the legislature specified by article 13 of the 1877 constitution. ${ }^{87}$ Thus, although the new constitution was not "revolutionary" even though placed on the ballot by drafters who had no right to do so, it would have been "revolutionary" had it received fewer legislative votes than required by the 1877 constitution for the accomplishment of different acts-the calling of a convention and the proposal of an amendment. Therefore, under the court's reasoning, article 13 of the 1877 constitution was both irrelevant to, and determinative of, the validity of the 1945 constitution.

The court sought to justify this contradiction in these words: "restricting by implication the legislative or any other branch of government, created by the constitution, is one thing; and restricting by implication the sovereign right and power of the people is another and altogether different thing."88 Yet if the legislature exceeded its implied bounds and placed a proposal on the ballot by the will of a simple majority of its members, would not the people still be free to ratify the proposal? This is to say that an unlimited power in the people to adopt organic law vitiates any legal or constitutional constraint on the power of the legislature to propose organic law.

Despite the logical flaws in its argument, the court had little difficulty finding that a valid election had been held, and declared the Constitution of 1945 "a valid and legal expression of the will of the people."89 It upheld that constitution, then, on a theory of popular sovereignty.
84. Wheeler, $200 \mathrm{Ga}$ at 334,37 S.E. $2 \mathrm{~d}$ at 329 .
85. Id.
86. Id.
87. Id.
88. Id.
89. Id. at 335,37 S.E. $2 \mathrm{~d}$ at 329 . 


\section{The Kentucky Decision}

The second major case to uphold a legislative attempt to avoid the rigors of the convention process was Gatewood v. Matthews, decided by the Kentucky Court of Appeals in $1966 .^{90}$

The Kentucky Constitution, promulgated in 1890, provides two methods by which it may be changed: (1) Section 256 permits amendments if proposed by a three-fifths majority of both chambers of the General Assembly and ratified by a majority of the electorate; ${ }^{91}$ and (2) section 258 allows revision by a constitutional convention without popular ratification, but the convention must be called by a "law" passed by two successive legislatures and ratified at the polls. ${ }^{92}$

The 1890 convention explicitly rejected a provision to preclude extratextual revision. A proposal "[t]hat the Constitution shall not be altered, amended or changed in any way" other than provided by the text was referred to committee; the convention never discussed it. ${ }^{93} \mathrm{~A}$ second proposal would have forbidden a convention called by means other than those provided by the document itself. ${ }^{94}$ Opponents protested that the convention could not bind future conventions, and that popular sovereignty required that the question of electoral ratification of future proposals be decided by legislatures elected by future popular sovereigns. ${ }^{95}$ Following this discussion, the author withdrew his proposal. ${ }^{96}$ While it is clear that the 1890 convention did not want to tie the hands of future conventions-even conventions called by a revolutionary act of the peo-

90. 403 S.W.2d 716 (Ky. 1966). The Kentucky Court of Appeals was the highest court of the state at the time this case was decided. The Kentucky Supreme Court was established in 1976. KY. CoNST. $\$ 110$ (effective January 1, 1976).

91. KY. CONST. $\S 256$. The Kentucky Constitution of 1891 remains the organic law of the state. Section 256 was amended by the voters in November 1979 to change the maximum number of amendments that might be proposed in a single election from two to four. This provision remains otherwise unchanged since the Gatewood decision.

92. KY. CONST. § 258. This provision remains unchanged since the Gatewood decision.

Although the Kentucky Constitution does not require that proposals adopted by the convention be presented to the electorate for ratification, the legislature has imposed this requirement by the terms of the convention call. The Kentucky courts have found an implied power in the legislature to do so. Gaines v. O'Connell, 305 Ky. 397, 204 S.W.2d 425 (1947).

Despite the use of the term "law," the concurrence of the governor is apparently not required for a referendum on a convention call. See Chenault v. Carter, 332 S.W.2d 623 (Ky. 1960).

93. I Debates of the Kentucky Constitutional Convention 143-44 (1890).

94. 2 Id. at 1632 . This suggestion apparently was intended by its author to guarantee that there would be no evasion of his proposal's additional requirement that convention proposals be submitted for electoral ratification before promulgation. Id. at 1634-35. Delegate Hanson Kennedy, who made the proposal, apparently believed that it was required to preserve the principle of popular sovereignty. He referred to the contemporaneous Mississippi Constitutional Convention, which had promulgated a constitution with an educational requirement for suffrage without presenting it for electoral ratification to avoid rejection by uneducated, recently freed, black voters. Kelinedy saw that promulgation as a decision justified by "expediency" but not "principle." Id. at 1635.

95. Id. at $1635-36$.

96. Id. at 1636 . 
$\mathrm{ple}^{97}$-it did not voice support for legislative power to effect extratextual revision.

Kentucky's political leaders had attempted constitutional revision for some thirty years before the Gatewood decision. In that time, the voters had rejected proposals to call unlimited conventions in 1931 and 1947 , a proposal to call a limited convention in 1959, and proposals to amend sections 256 and 258 in 1951 and $1963 .{ }^{98}$

In 1962, the legislature again proposed to call a limited convention..$^{99}$ Rather than approve this proposal and present it to the voters, the 1964 General Assembly instead established a Constitutional Revision Assembly. ${ }^{100}$ The Revision Assembly voted in May 1965 to recommend that the Governor include in his call of an extraordinary legislative session for 1965 the issue of whether to call a constitutional convention limited to the consideration of a draft constitution to be adopted by the Revision Assembly. ${ }^{101}$ It did so apparently to give the 1966 legislature the option of using the convention procedure to ratify the proposed constitution, and in so domg, rejected an argument made by Delegate Tom Waller that no constitutional convention was required. ${ }^{102}$ Waller's argument that section 4 of the state's Bill of Rights allowed the legislature to place the draft constitution directly on the ballot, foregoing a convention altogether, did not convince the Revision Assembly to foreclose the option of seeking ratification by the textual convention method. ${ }^{103}$ The Assembly unanimously approved a draft constitution in December 1965. ${ }^{104}$ The legislature voted by large margins not to seek ratification

97. Delegate Kennedy, who submitted both proposals to preclude extratextual revision, supported the people's right to make organic law by revolutionary means. See id. at 1635 .

98. Oberst \& Wells, Constitutional Reform in Kentucky_The 1966 Proposal, 55 KY. L.J. 50, 52-56 (1966). Also defeated in the 1963 election was a constitutional amendment to eliminate the ceilings on the salaries of state officials established by the constitution. Id. at 56.

The term "limited" convention as used herein refers to a convention limited to the consideration of specified subjects or proposals enumerated in the convention call.

99. Id. at 56.

100. Id. The Revision Assembly included the state's 7 living former governors and 43 delegates appointed by a committee consisting of the Governor, the Lieutenant Governor, the Speaker of the House of Representatives, and the Chief Justice of the Court of Appeals. Id. at 57. Five delegates were appointed at large, while the remaining 38 represented the state's senatorial districts. Id. at 57; see also Gatewood v. Matthews, 403 S.W.2d 716, 717 (Ky. 1966).

The legislature possessed no explicit constitutional authority to establish such a commission. Gatewood, 403 S.W.2d at 718.

James B. Milliken, chief justice of the Kentucky Court of Appeals until January 1965, served on the Constitution Revision Assembly. REPORT OF THE [KENTUCKY] CONSTITUTION REview Commission 3 (1950). Though Milliken sat on the Gatewood case as an associate justice, the court's decision does not discuss his apparent confict of interest.

101. Oberst \& Wells, supra note 98 , at 57-58.

102. Id. at 58-59.

103. Id.

104. Id. at 58. 
by convention; instead it placed the proposal directly on the fall ballot. ${ }^{105}$

Before doing so, however, the legislature amended the Revision Assembly's proposal to change provisions regarding elections and the terms of, and succession in, public office. ${ }^{106}$ The draft was a thorough revision and modernization of the Constitution of 1891. It eliminated a wealth of detail and all but a few statewide elective offices; extended the terms of office of state representatives and senators to four and six years, respectively; reorganized the courts; and granted the General Assembly plenary power over the structure of local governments. ${ }^{107}$ A provision to eliminate constitutional restrictions on the salaries of public officials and to grant the legislature authority to set those salaries by statute was described by a commentator as "[o]ne of the most significant changes." ${ }^{108}$ The voters of Kentucky had rejected a similar proposal to eliminate the salary ceiling just three years earlier. ${ }^{109}$

The trial court sustained the actions of the legislature in a suit filed to challenge the proposed constitution. ${ }^{110}$ The court held that the amendment procedures of sections 256 and 258 were not exclusive because, under section 4 of the State's Bill of Rights, the people retained the right to consider proposals for constitutional change presented in other ways. ${ }^{111}$ Section 4, modeled after language in the Declaration of Independence, states:

All power is inherent in the people, and all free governments are founded on their authority and instituted for their peace, safety, happiness, and the protection of property. For the advancement of these ends, they have at all times an inalienable and indefeasible right to alter, reform or abol-

105. Id. at 62 . The proposal was adopted by margins of 32-0 in the Senate and 79-17 in the House. Id. Oberst and Wells suggest that the legislature chose the extratextual method to avoid the lengthy delays associated with calling a convention; they write:

[T] here was the matter of practical politics. The people had rejected proposals for conventions three times before. Would the people risk an unlimited convention even with the safeguard of resubmission [of the convention's draft for voter approval]? Finally, why go to all that trouble when the excellent document drafted by the [Revision] Assembly was Id. at 61 . already at hand?

106. Bebout, Constitutions and Constitutional Revision, in COUNCIL of STATE GovernmenTS, THE BOOK OF THE STATES 11 (1968 ed.). The legislature's Research Commission produced a lineby-line analysis and comparison of the constitution of 1891 and the proposed revision of 1966 . J. Fleming \& J. Reeves, A Comparison: The Present, The Proposed Kentucky CoNSTrTUtions (Kentucky Legislative Research Commission Informational Bulletin No. 52, 1967).

107. Bebout, supra note 106, at 11-12.

108. Id. at 12 .

109. Oberst \& Wells, supra note 98 , at 56.

110. Less than a week after the proposal was delivered to the governor, W.C. Gatewood, described by commentators as "a Boone County farmer," brought suit against the attorney general and secretary of state of Kentucky. Gatewood sought both a declaration that the legislative proposal was invalid and an injunction against the election. Gatewood v. Matthews, 403 S.W.2d 716, 717 (Ky. 1966); Oberst \& Wells, supra note 98, at 62-63.

111. Gatewood, 403 S.W.2d at 717; Oberst \& Wells, supra note 98, at 63-64. 
ish their government in such manner as they may deem proper. ${ }^{112}$

Barely a month after the trial court rendered its opinion, the Kentucky Court of Appeals upheld the legislature's action by a vote of 6-1. ${ }^{113}$ Judge Williams began his majority opinion by distinguishing the body of cases requiring "precise" compliance with the terms of sections 256 and 258. ${ }^{14}$ He observed that "[i]n no case have we held that sections 256 and 258 are the exclusive modes of changing the constitution." 115 Though these provisions must be followed precisely if they are used, he continued, "the people" may ignore these procedures altogether. ${ }^{116}$ In other words, sections 256 and 258 must be followed precisely or ignored completely; the court would allow no middle course of substantial compliance.

Because there was no textual authority for the procedure chosen by the 1964 General Assembly, the court reasoned that "[i]f there be authority for such action it must be derived from the sovereign power of the people as delineated in section 4 of the Bill of Rights." 117 Like the Wheeler court which it cited, ${ }^{18}$ the Gatewood court found the right of revolution to be an independent source of authority for constitutional change. There is, however, an important distinction between the two cases: The Wheeler court validated a constitution after it had been ratified, while in Gatewood the election had not yet been held. ${ }^{19}$ The Gatewood court held that the popular right of revolution empowered the legislature to solicit revolution by drafting a constitution, with the hope that the electorate might later "cure" their lack of authority to do so.

In further support of its view that sections 256 and 258 did not exclude other means of change, the Kentucky court noted first the rejection by the 1890 convention of proposals to forbid extratextual revision, ${ }^{120}$ and second, section 26 of the 1890 constitution which provides:

To guard against transgression of the high powers which we have delegated, We Declare that everything in the Bill of Rights is excepted out of the general powers of government, and shall forever remain inviolate;

112. KY. CONST. § 4. Thomas Jefferson reputedly wrote this provision. Oberst \& Wells, supra note 98 , at 51. Like article 1 , section 5 , paragraph 1 of the Georgia Constitution, discussed supra text accompanying notes $81-86$, this provision echoes the Declaration of Independence. See supra note 83. It has appeared in every Kentucky Constitution and is substantially unchanged since its inclusion in the state's first constitution. See KY. CONST. of 1792, art. XII, $\S 2$.

113. Gatewood, 403 S.W.2d at 722; Oberst \& Wells, supra note 98, at 63.

114. Gatewood, 403 S.W.2d at 718.

115. Id.

116. Id.

117. Id.

118. Id. at 720 .

119. Wheeler v. Board of Trustees, $200 \mathrm{Ga} .323,329-30,37$ S.E.2d 322, 327 (1946); Gatewood, 403 S.W.2d at 717.

120. Gatewood, 403 S.W.2d at 719; 1 Debates of The Kentucky Constitutional CONVENTION, supra note 93, at 144; see also supra text accompanying notes 93-97. 
and all laws contrary thereto, or contrary to this Constitution, shall be void. ${ }^{121}$

Section 26, the court held, made the Bill of Rights-not the constitution as a whole-the supreme law of Kentucky. This, they claimed, buttressed the argument that section 4 of the Bill of Rights provided authority for extratextual revision. ${ }^{122}$

Like the Georgia court before it, the Kentucky court articulated conditions under which the popular power to revise the constitution could be exercised: So long as the people have due and proper notice and opportunity to acquaint themselves with any revision, and make their choice directly by a free and popular election, their will is supreme and it is to be done. ${ }^{123}$ The court believed that the events of 1966 had fulfilled the requirements of adequate notice, deliberation, and popular sovereignty. The media had brought the issues to the attention of the people, ${ }^{124}$ two successive legislatures had debated the draft constitution, and the opportunity for a direct popular vote ensured popular sovereignty. ${ }^{125}$ The process had served the spirit of section 258, if not its letter.

Kentucky voters rejected the proposed constitution that fall. ${ }^{126}$

\section{B. The Necessity Rationale}

Both the Georgia Supreme Court and the Kentucky Court of Appeals based their decisions in favor of extratextual revision on the doctrine of popular sovereignty. Commentators have offered a related but different rationale, the doctrine of necessity. ${ }^{127}$ As outlined above, the processes of amending and revising a constitution are cumbersome and time consuming. ${ }^{128}$ The Kentucky constitution, for example, requires multiple elections and perhaps six or more years to call a convention and adopt a new constitution. ${ }^{129}$ The task of achieving political consensus and maintaining it over so long a period can be quite daunting. ${ }^{130}$ Because revision by the terms of the constitution is thus practically

121. KY. CONST. $\S 26$. This provision, which seems quite unusual among the state constitutions, derives from Kentucky's first constitution and has remained essentially unchanged since that time. See KY. ConsT. of 1792, art. XII, § 28.

122. Gatewood, 403 S.W.2d at 718-19.

123. Id. at 721 .

124. The modern media, the court argued, obviated the need for a lengthy process to assure that the people of the state were adequately informed because communication was pervasive and rapid. Id.

125. Id.

126. N.Y. Times, Nov. 9, 1966, at 28, col. 6.

127. See, e.g., Oberst \& Wells, supra note 98 , at 120.

128. See supra text accompanying notes 23-38.

129. KY. ConST. § 258; Oberst \& Wells, supra note 98, at 60-61.

130. See, e.g., Oberst \& Wells, supra note 98, at 60-62 (discussing rationale of Kentucky Legislature for seeking to avoid the requirements of $\S 258$ ); see also id. at 53-56 (discussing failed efforts to reform Kentucky Constitution). 
impossible, some commentators argue that revision by extratextual means is "necessary." 131

The necessity argument ignores the fact that amendment provisions can themselves be changed-albeit by the extant procedure. ${ }^{132}$ Developing and maintaining political consensus on such a procedural question should be politically feasible, especially if the proponents of the necessity rationale are correct in their argument that the textually provided mechanisms of revision and amendment are obsolete. ${ }^{133}$ Such an effort was made in Kentucky. ${ }^{134}$ Its failure may be read, as proponents of the necessity rationale read $i{ }^{135}$ to demonstrate the futility of trying to alter burdensome revision procedures on their own terms. It may also be read as evidence that "the people" did not support the change. The electoral defeat of the constitution at issue in Gatewood may support this conclusion as well. ${ }^{136}$

These are the rationales for extratextual revision. Now let us turn to the counterarguments.

\section{III}

\section{The Argument Against Extratextual Revision}

\section{A. Constitutional Texts are Best Interpreted to Forbid Extratextual Revision}

Several courts have held that the constitutions of their states prohibit amendment by extratextual means. ${ }^{137}$ The leading authority for

131. See id. at 120. The authors state: "Circumvention of the prescriptions for revision set out in the [Kentucky] Constitution of 1891 was allowed on the assumption that these provisions are unworkable. State political history as presented in this paper supports the assumption." Id.

132. See sources cited supra note 23. Florida had a history of failed attempts at constitutional reform similar to Kentucky's. Nonetheless, the amendment procedure established by the constitutional text was utilized to achieve reform. See generally Sturm, supra note 41 (detailing history of the revision of Florida's constitutions). The current Florida Constitution provides multiple avenues for constitutional change. See infra note 181 .

133. The point here is merely that if the people are convinced of the need to change the amendment and revision procedures, they are likely to adopt a proposal to do so. I also believe that it is easier to achieve consensus about a fair process for making decisions than about the substance of the decisions themselves: For example, Democrats and Republicans may both support winner-takeall elections for the U.S. Congress but are unlikely to back the same candidates. I recognize that this latter point is not self-evident, but it is of subsidiary importance given that Kentucky's voters did not appear to perceive a need for a simpler amendment procedure.

134. Oberst \& Wells, supra note 98 , at 55.

135. Id. at 120 ("revision via constitutional provisions was politically impossible").

136. See Recent Case, 81 HARv. L. REv. 693, 697 (1968).

137. See, e.g., State v. Manley, 441 So. 2d 864 (Ala. 1983) (enjoining election to ratify new constitution proposed via amendment procedures); McFadden v. Jordan, $32 \mathrm{Cal}$. 2d 330, 196 P.2d 787 (1948) (rejecting initiative proposal which would have effectively revised constitution); Opinion of the Justices, 264 A.2d 342 (Del. 1970) (advisory opinion holding that while constitutional revision by a series of amendments was not invalid per se, each proposed amendment would face scrutiny under the non-revision test); Adams v. Gunter, 238 So. 2d 824 (Fla. 1970) (rejecting amendment 
this position is the unanimous decision of the California Supreme Court in McFadden v. Jordan. ${ }^{138}$

The California constitution permits the proposal of both statutes and constitutional amendments by initiative petition. ${ }^{139}$ Constitutional amendments are as easily proposed as statutes, except that more signatures must be collected on the initiative petitions. ${ }^{140}$ The constitution may also be amended by a proposal adopted by two-thirds of the legislature and ratified at the polls. ${ }^{141}$ Constitutional revision, on the other hand, requires: (1) a call adopted by two-thirds of the legislature and ratified at the polls, (2) the election of a convention, (3) adoption of a revision by the convention, and (4) ratification of the convention's proposal by the voters. ${ }^{142}$

In 1948, the proponents of the "California Bill of Rights" circulated an initiative petition to place the constitutional amendment on the November ballot. ${ }^{143}$ The proposed amendment was extremely broad; it included 12 sections, 208 subsections, and more than 21,000 words. The existing constitution, in comparison, contamed 25 articles, 347 sections, and some 55,000 words. ${ }^{144}$ The proposal included highly specific provisions on a variety of subjects, including pensions, gambling, taxes, margarine, medicine, civic centers, legislative reapportioninent, elections, legislative committees, fish, game, pubhic lands, and miming. ${ }^{145}$ The proposal would have revised the existing constitution extensively.

Opponents of the proposal, mcludimg prominent members of the state bar, petitioned the state supreme court for a writ of mandate to

designed to establish a unicameral legislature as invalid under the non-revision rule); Rivera-Cruz v. Gray, 104 So. 2d 501 (Fla. 1958) (invalidating attempt to amend state constitution by a series of 14 amendments each of which provided that it would not go into effect unless all others were also adopted); Ellingham v. Dye, 178 Ind. 336, 99 N.E. 1 (invalidating as unconstitutional a statute which would have placed constitution drafted by the legislature on the ballot for ratification), appeal dismissed, 23 U.S. 250 (1912); Holmes v. Appling, 237 Or. 546, 392 P.2d 636 (1964) (refusing attempt to revise constitution by popular initiative).

138. 32 Cal. 2d 330, 196 P.2d 787 (1948). The amendment-revision distinction made by the McFadden court was articulated as early as 1911 by the North Dakota Supreme Court in State ex rel. Miller v. Taylor, 22 N.D. 362, 133 N.W. 1046, and was discussed extensively a year later in Ellingham v. Dye, 178 Ind. 336, 99 N.E. 1 (1912). Nonetheless, the McFadden decision is the most often cited, having been relied upon by several courts including those of Alabama, Manley, 441 So. 2d at 875; Delaware, Opinion of the Justices, 264 A.2d at 346; and Florida, Rivera-Cruz, 104 So. 2d at 504.

139. CAL. CONST. art. II, $\S \S 8,10$. At the time of the McFadden decision these provisions were found in article IV, $\S 1$.

140. Id. Article II, $\S 8(\mathrm{~b})$ requires initiative statute petitions to be signed by registered voters numbering $5 \%$ of the vote cast in the last gubernatorial election; initiative constitutional amendment petitions require signatures totaling $8 \%$ of that number.

141. Id. art. XVIII, $\S \S 1,4$.

142. Id. art. XVIII, $\S \S 2,4$.

143. McFadden, 32 Cal. $2 d$ at 331,339 n.2, 196 P.2d at 788,793 n.2.

144. Id. at 334,196 P.2d at 790.

145. Id. at $334-39,196$ P.2d at $790-93$. 
prevent the Secretary of State from placing the proposal on the ballot. ${ }^{146}$ The court concluded that the writ should issue because the constitution forbade the use of amendment procedures to accomplish a revision. ${ }^{147}$

The court observed that the constitution provided separate, detailed procedures for amendment and revision. ${ }^{148}$ The court reasoned that the provision of two elaborate procedures, one for "amendment" and one for "revision," required that those terms have distinct meanings: "The differentiation required is not merely between two words; more accurately, it is between two procedures and their respective fields of application."149 The adoption of both a "relatively simple" amendment procedure and a complex revision procedure, which established a "formidable bulwark" against revision, made clear that the framers of the state constitution intended a "real difference" to be maintained between amendments and revisions. ${ }^{150}$

This interpretation of the amendment and revision procedures implied a "non-revision" limitation on the power to amend the state constitution: Any proposed amendment "so broad that . . . a substantial revision of our present state Constitution would be effected ... may not properly be submitted to the electorate . . . unless it is first agreed upon by a constitutional convention."151 Because the "California Bill of Rights" failed this test, the court enjomed the election. ${ }^{152}$

McFadden v. Jordan forbids extratextual revision because the court beheved that the best interpretation of a constitution with distinct amendment and revision procedures excludes other means of legal change. The provision of a complicated and cumbersome revision procedure that might be avoided by more expeditious extratextual procedures would have been "an indulgence in idle curiosity and speculation."153 To put the point differently, why would the drafters place obstacles to constitutional reform in the text if easier extratextual routes were to be avail-

146. Id. at 331, 196 P.2d at 788. Counsel for petitioner included Matthew O. Tobriner, who later served as an associate justice of the California Supreme Court. Id. The proponents of the amendment participated in the case as intervenors. Id. at 331, $196 \mathrm{P} .2 \mathrm{~d}$ at 788 .

147. Id. at $331-32,196 \mathrm{P} .2 \mathrm{~d}$ at 788 .

148. Id. at $332,196 \mathrm{P} .2 \mathrm{~d}$ at 789 .

149. Id. at 347,196 P.2d at 797.

150. Id. In the court's view, the 1911 adoption of the provision for initiative constitutional amendments did not signal a retreat from that distinction and should be read to maintain it. Id. at 334, 347, 196 P.2d at 789-90, 798. The court also argued that its 1894 decision in Livermore v. Waite, 102 Cal. 113, 36 P. 424 (1894), recognizing the amendment-revision distinction, had been implicitly accepted by the drafters of the 1911 amendment establishing the constitutional initiative, because it was not explicitly rejected by the terms of that amendment. McFadden, 32 Cal. $2 \mathrm{~d}$ at 332 , 196 P.2d at 789.

151. McFadden, 32 Cal. 2d at 334, 196 P.2d at 790.

152. Id. at $350-51,196 \mathrm{P} .2 \mathrm{~d}$ at $799-800$.

153. The quoted phrase is that of Kentucky's Justice Hill. Gatewood v. Matthews, 403 S.W.2d 716, 722 (Ky. 1966) (Hill, J., dissenting). 
able? The court therefore concluded that the provisions for amendment and revision should be interpreted to exclude other means of constitutional change.

\section{B. Extratextual Constitutional Change is Inconsistent with Limited Constitutional Government}

A basic precept of American political ideology is that political authority is derived solely from the consent of the governed-that is, government derives its moral and political force from the will of the people. ${ }^{154}$

Apart from town meetings, however, American government is not a direct democracy. Instead, the popular sovereign has, through written constitutions, established governments and delegated to them limited authority to act for the people. ${ }^{155}$ These constitutions limit the power both of the government and of popular majorities. ${ }^{156}$ This follows from the very notion that constitutional courts may protect the rights of individuals by voiding statutes passed by representatives of a majority of the people.

A written constitution is normally viewed as a body of law infrequently to be amended or revised, but must nonetheless serve a changing society. Such a constitution must necessarily be interpreted. This is so because broad principles suitable for long usage cannot provide sufficient detail for the variety of circumstances that may arise. ${ }^{157}$ Who should interpret constitutions and what role the judiciary should play, have, of course, been the subjects of intense debate. ${ }^{158}$ But whoever is to interpret organic law must preserve the will of the popular sovereign against attempts by the government to exceed its limited authority. ${ }^{159}$

154. T. Cooley, A Treatise on the Constitutional Limitations 28 (Boston 1868 \& photo. reprint 1972) ("[t]he theory of our political system is that the ultimate sovereignty is in the people, from whom springs all legitimate authority"). See also supra note 83; U.S. CoNST. amends. IX, $\mathrm{X}$.

155. T. COOLEY, supra note 154 , at 28.

156. Id. at 2-3, 28. Cooley wrote:

In American constitutional law the word constitution is used in a restricted sense, as implying the written instrument agreed upon by the people of the Union, or of any one of the States, as the absolute rule of action and decision for all departments and officers of the government, in respect to all the points covered by it, until it shall be changed by the authority which established it, and in opposition to which any act or rule of any department or officer of the government, or even of the people themselves, will be altogether void.

Id. at 3 (emphasis added).

157. Id. at 39 .

158. The debate over judicial review has provoked a wealth of political and academic writing. See, e.g., Marbury v. Madison, 5 U.S. (1 Cranch) 137 (1803); ThE Federalist No. 78 (A. Hamilton); A. Bickel, The Least Dangerous Branch (1962); J. Choper, Judicial Review and the National Political Process (1980); J. Ely, Democracy and Distrust (1980).

159. The Federalist No. 78, at 469-70 (A. Hamilton) (C. Rossiter ed. 1961). 
Some also argue that a constitution limits the legal power of the people as well as the power of a legislative majority. They assert that the people may evade a constitutional provision only by amending the document in a legal fashion or by an extraconstitutional or revolutionary act. ${ }^{160}$ Under this view, a constitution facilitates and directs constitutional revision by providing ground rules for its accomplishment.

In short, American political principles suppose that legitimate government is limited constitutional government subject to the will of the people. To quote the famous phrase, ours is "a government of laws and not of men."161

Since American governments are limited in their power by written constitutions, the issue becomes this: Does extratextual revision comport with the principles of American government, as three state courts have ruled? In the sections that follow, I argue that it does not.

\section{Extratextual Revision Undermines the Distinction Between Revolutionary and Legal Change}

At one level, the distinction between "revolutionary" and "legal" constitutional change is clear. There is an obvious difference between change effected by force or otherwise without textual authority and change accomplished in accordance with written constitutional provisions. At another level, however, the distinction is obscure. The American Revolution is a prime example of revolutionary constitutional change. That it was accomplished through violence, however, does not undermine the moral and legal force of our constitutional regime. ${ }^{162}$ When change is achieved "legally" - that is, as provided by the constitution-it derives its legitimacy from the popular will that underlies the constitution itself. ${ }^{163}$ If change is valid whether by revolution or legal amendment, why is any distinction necessary?

One distinction between legal and revolutionary change is that legal acts are within the authority of government acting alone, while revolutionary acts-whether by government or any other actor who presumes

160. Id.; T. Cooley, supra note 154, at 3-4; Wheeler v. Board of Trustees, 200 Ga. 323, 334, 37 S.E.2d 322, 329 (1946) ("Ii]f a constitution is to be a legal one, as distinguished from a revolutionary constitution, it must be adopted by the people by a compliance with the legal machinery in operation at the time of its adoption in order to obtain a legal expression of the will of the people").

This argument can be stated in tautological terms: If the people do not act "legally," they act as revolutionaries. Perhaps no precise distinction between law and revolution can be formulated, but as is discussed in the next section, each term possesses some core of meaning that requires that a distinction between them be maintained. See infra text accompanying notes 162-69.

161. J. ADAMS, DRAFT MassáchusetTS CONSTITUTION: DeClaRation OF Rights art. XXX (1779).

162. See, e.g., Wheeler, $200 \mathrm{Ga}$ at 332, 37 S.E.2d at 328; Smith v. Cenarrusa, 93 Idaho 818, 821-22, 475 P.2d 11, 14 (1970); see also The Federalist No. 40 (J. Madison).

163. See T. CoOLEY, supra note 154 , at 31 . 
to act for the people-are invalid unless ratified by the people. Accordingly, the American constitution is law, despite the absence of legal authority in the Constitutional Convention to draft it, because it was ratified; the constitution at issue in Gatewood never held legal force because it was not ratified. ${ }^{164}$

Extratextual constitutional revision undermines the distinction between revolutionary and legal change. The Gatewood and Wheeler courts both declared extratextual revisions to be "legal."165 Yet in each case this "legal" change was permissible only under the right of revolution expressed in the respective state constitutions. ${ }^{166}$ By giving legal force to acts legitimated by the popular right of revolution, these courts failed to inaintain a clear distinction between the two kinds of authority. The courts treated decisions to forego the textual procedures as legislative actions in conformity with those provisions. Decisions of the first sort have the force of law when ratified by the people exercising the popular right of revolution, while the latter become law because the constitution was followed. Despite this difference, the revolutionary act is treated identically with the legal act.

The Gatewood and Wheeler courts invite confusion when they suggest that extratextual revision might be treated as inerely an exercise of power under a constitutional provision reserving the right to revolution. They thus confuse the power of the people to exercise that right with government power to circumvent the textual revision procedures. To confuse legal with revolutionary acts is to confuse the limited constitutional power of governinent with the plenary power of the popular sovereign. If the governinent inay define its own authority by exercising that popular power, it becomes sovereign in its own right. ${ }^{167}$ If a governinental act is law inerely because the government so decrees, then the will of the government becomes law. We would then have a governinent of "men" rather than of "law."168

To maintain a clear distinction between legal and revolutionary acts, courts should refuse to allow revolutionary action by those who, like the legislature, possess only legal authority. At a ininimum, the judiciary

164. See N.Y. Times, Nov. 9, 1966, at 28, col. 6.

165. Wheeler, $200 \mathrm{Ga}$ at 335, 37 S.E.2d at 329; Gatewood v. Matthews, 403 S.W.2d 716, 721 (Ky. 1966).

166. Wheeler, $200 \mathrm{Ga}$ at 333, 37 S.E.2d at 329; Gatewood, 403 S.W.2d at 720.

167. See Smith v. Cenarrusa, 93 Idaho 818, 825, 475 P.2d 11, 18 (McFadden, C.J., dissenting); Ellingham v. Dye, 178 Ind. 336, 347, 99 N.E. 1, 5 (1912); Gatewood, 403 S.W.2d at 723-24 (Hill, J., dissenting); see also T. COOLEY, supra note 154, at 32, 85-87, 172-77; J. JAMESON, supra note 56, at 490-91.

168. This resulting sovereignty in government is identical with the omnipotence of Parliament in the United Kingdom, which commentators offer as the antithesis of limited, popular government. See, e.g., T. Cooley, supra note 154, at 3-4; see also sources cited supra note 167. 
should clearly label revolutionary acts as such. ${ }^{169}$

\section{Failure to Distinguish Legal from Revolutionary Change Encourages Government to Exceed its Limited Authority}

Unless revolutionary acts are labeled as such, government actors will be encouraged to usurp powers denied them by the constitution. Both the Kentucky Constitution and the Georgia Constitution of 1877, for example, explicitly assign the power to draft a revised constitution to a popularly elected convention. ${ }^{170}$ By presenting documents drafted under their own supervision for electoral ratification, the legislatures assumed the constitutional role of the conventions.

If we accept extratextual revision, we countenance legislative usurpation. The need to discourage such usurpation constitutes a second reason for interpreting amendment and revision provisions as the exclusive means of valid constitutional change. After all, the legislature has powerful incentives to assume the convention's role. First, a convention elected from districts-which may coincide with legislative districtsestablishes a body of political actors who might provide electoral competition for the legislators. ${ }^{171}$ By circumventing the convention process, the legislature can forestall the creation of this class of political competitors. Second, because an important function of any written constitution is to limit legislative power, ${ }^{172}$ a legislature may enhance its own power by drafting favorable revisions. For reasons discussed more fully below, such proposals may be ratified despite opposition to an enhanced legislative role. ${ }^{173}$

169. For the judiciary to label such an act "revolutionary" could lead to various results: judicial abstention, judicial opposition to reform, or a ruling that the change is valid only as a revolution is valid-because the people so choose. Admittedly, I beg the difficult question of how a court should decide a case involving an attempted extratextual revision. However, any of these outcomes is preferable, in my view, to labeling such conduct "legal," because each sharply defines the limits of law. This point is more fully discussed below. See infra text accompanying notes 170-75.

170. KY. ConsT. $\S 258$; GA. ConsT. of 1877 , art. 13. $\S 1$, para. 2.

171. Many constitutions require convention delegates to be elected from legislative districts. Colo. CONST. art. XIX, § 1; DEL. CONST. art. XVI, § 2; FLA. CONST. art. XI, § 3; ILL. ConST. art.

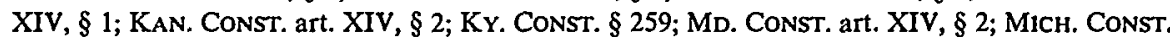
art. XII, $\S 3$; MINN. CoNST. art. IX, § 2; Mo. ConST. art. XII, § 3(a); MonT. ConsT. art. XIV, § 4; N.H. Consr. part 2, art. 100, § b; N.Y. Consr. art. X1X, § 2; N.C. Consr. art. XIII, § 1; R.1. CoNST. amend. XLII, $\S 2$; S.D. CONST. art. XXIII, $\S 2$. Even in states with no constitutional requirement that the convention delegates be elected from legislative districts, it is often convenient to choose them in that fashion. For example, the Revision Commission appointed by the Kentucky Legislature to draft the constitution at issue in Gatewood was selected from senatorial districts absent a constitutional requirement to do so. Oberst \& Wells, supra note 98, at 57.

172. T. COOLEY, supra note 154, at 85 ("the legislatures of the American States are not the sovereign authority, and, though vested with the exercise of one branch of the sovereignty, they are nevertheless, in wielding it, hedged in on all sides by important limitations, some of which are imposed in express terms, and others by implication which are equally imperative").

173. See infra text accompanying notes $183-230$. 
Constitutional drafters may assign the task of revision to a convention independent of the legislature solely to prevent the legislature from enhancing its power in this fashion. This choice reflects the familiar view that "[n]o man is allowed to be a judge in his own cause because his interest would certamly bias his judgment, and, not improbably, corrupt his integrity." 174 The self-serving nature of many provisions of the constitutions proposed by the legislatures in Wheeler and Gatewood demonstrates this problem. ${ }^{175}$ If a people, conscious of the legislature's inclination to enhance its power and to protect its members from political competition, deliberately delegated the revision power to a convention, the courts must preserve that delegation or undermine the capacity of their constitution to restram government.

In conclusion, extratextual revision is inconsistent with the principle of limited constitutional government because it allows the government to exceed its legitimate power by exercising the popular right of revolution, undermines the clear distinction between legal and revolutionary change, and encourages legislative usurpation of roles constitutionally assigned to other actors. For these reasons, the Gatewood and Wheeler cases were wrongly decided, though as Part IV argues, they are objectionable on other grounds as well.

IV

The Argument for Cumbersome Revision PROCEDURES

An examination of state constitutions adopted in recent years reveals a trend toward the simplification of textual procedures for constitutional change. Recently fashioned methods of constitutional change include provisions that allow legislatures to place revisions on the ballot for popular ratification ${ }^{176}$ - the very practice allowed without textual authorization by the decisions criticized above-and provisions that require a state officer to place the question of whether to call a convention on the ballot every few years. ${ }^{177}$ Of the twelve constitutions adopted

174. The Federalist No. 10, at 79 (J. Madison) (C. Rossiter ed. 1961). For additional support for this argument that the legislature will perceive a convention as a political threat, see Sturm, supra note 41 , at 591 .

175. See supra text accompanying notes $67-69,106-09$.

176. See supra note 33 and sources cited therein.

177. Fourteen state constitutions require periodic votes on whether to call a constitutional convention. AlASKA CONST. art. XIII, $\S 3$ (10 years); CONN. CONST. art. XIII, § 2 (20 years); HAw. CONST. art. XVII, $\S 2$ (9 years); ILl. Const. art. XIV, $\S 1$ (20 years); IowA ConsT. art. X, $\S 3$ (10 years); MD. ConST. art. XIV, § 2 (20 years); MICH. ConST. art. XII, § 3 (16 years); Mo. CONST. art. XII, $\S 3$ (a) (20 years); MONT. CONST. art. XIV, $\S 3$ (20 years); N.H. ConST. part 2, art. $100, \S$ b (10 years); N.Y. CONST. art. XIX, $\S 2$ (20 years); OHIo CONST. art. XVI, $\$ 3$ (20 years); OKLA. CONST. art. XXIV, § 2 (20 years); R.I. CONST. amend. XLII, § 2 (10 years). 
since 1960 , eight include one or both of these innovations. ${ }^{178}$

The most dramatic example is the Florida Revised Constitution of 1968. Florida has a history of failed revision efforts. ${ }^{179}$ The 1968 constitution, adopted as a series of three amendments proposed by the legislature, ${ }^{180}$ included six methods of constitutional change ${ }^{181}$ - more than any other state constitution.

In addition, we have seen that some courts have allowed evasion of the cumbersome requirements that still exist. ${ }^{182}$ Thus, both constitutional drafters and courts have rejected the rationale for the older, more cumbersome revision procedures. These efforts to expedite constitutional change are ill advised and threaten such constitutional values as popular sovereignty, political stability, and minority rights.

\section{A. Cumbersome Revision Provisions Better Preserve Popular Sovereignty}

\section{Elections Provide a Flawed Measure of Popular Sentiment}

The Wheeler and Gatewood courts argue that electoral ratification "cures" irregnlarities in the proposal of amendments and revisions. ${ }^{183}$ Drafters could similarly justify expeditious constitutional revision procedures by argning that they reserve to the electorate the power to ratify proposed revisions. These arguments may well justify a court's acquiescence in extratextual revision in order to give effect to the right of revolu-

178. The twelve documents and their dates of ratification are: ARK. CONST. (1974); CONN. CONST. (1965); FlA. CONST. (1968); GA. CONST. (1976); HAW. CONST. (1978); ILL. CONST. (1970); LA. Const. (1975); Mich. Const. (1963); MONT. CONST. (1972); N.C. ConsT. (1970); PA. CoNST. (1968); VA. CONST. (1971).

Four of these state constitutions allow the legislature to propose a revision: Florida, Georgia, Hawaii, and North Carolina. See sources cited supra note 33. Five require periodic submission of the convention call question: Connecticut, Hawaii, Illinois, Michigan, and Montana. See sources cited supra note 177.

179. See, e.g., Adams v. Gunter, 238 So. 2d 824 (Fla. 1970); Rivera-Cruz v. Gray, 104 So. 2d 501 (Fla. 1958).

180. Sturm, supra note 41 , at 592 .

181. The Florida Revised Constitution of 1968 may be amended in the following ways: amendments may be proposed by the legislature, FLA. CONST. art XI, $\S 1$; revisions may be proposed by the legislature, $i d$; amendments may be proposed by initiative, $i d$. $\S 3$; a constitutional convention to propose revisions may be called by initiative, id. $\S 4$; amendments may be proposed by a constitutional revision commission, id. $\S 2$; and, finally, revisions may be proposed by the revision commission. Id.

See also Sturm, supra note 41 , at 593 . The ease with which the Florida constitution may be amended has been criticized because of the potential for legislative abuse. Note, Legislative Efforis to Amend the Florida Constitution: The Implications of Smathers v. Smith, S FLA. ST. U.L. REV. 747 (1977).

For a discussion of trends in state constitutional developments, see the chapters of the present and past volumes of the Book of the States on state constitutions. THE COUNCIL OF STATE GOVERNMENTS, supra note 26.

182. See supra text accompanying notes 52-136.

183. See supra text accompanying notes 79-82, 117-25. 
tion, ${ }^{184}$ but they nonetheless rest on an unrealistic conception of modern elections. For a variety of reasons, the outcome of a single election is less likely to provide a meaningful expression of the will of the people than the outcome of the complex textual procedures.

First is the danger of log-rolling-that is, the aggregation of separate minorities favoring distinct aspects of a proposal to form an illusory majority. ${ }^{185}$ The common requirement that amendment proposals be limited to a single subject reflects the concern of constitutional framers with this problem. ${ }^{186}$ The single subject rule cannot be applied to revision proposals, which by definition alter many constitutional provisions. ${ }^{187}$ It is precisely because they address multifarious subjects that revision proposals invite log-rollimg.

Second, an electoral majority is simply that-a majority of those who vote. The low turnouts of modern American elections make clear that electoral outcomes are determined by a mere fraction of the people. ${ }^{188}$ Participation may be especially low for ballot questions as compared to other elections. ${ }^{189}$ More troubling than nonparticipation is the likelihood that the electorate will differ from the total adult population in significant ways. ${ }^{190}$ As one author writing about Califorma elections observes: "Typically, lower socioeconomic groups-minorities, the poor, the uneducated-vote in smaller relative numbers than do more privi-

184. Acquiescing in popular revolution is not the same as allowing extratextual revision as a matter of law. See supra note 169 and text accompanying notes 170-75.

185. This danger has been observed by courts adopting the non-revision limitation on the amendment power. See, e.g., McFadden v. Jordan, 32 Cal. 2d 330, 346, 196 P.2d 787, 797 (1948).

186. See sources cited supra note 24.

187. See supra text accompanying note 27.

188. In national elections from 1970 to 1984 , the percentage of the voting age population going to the polls exceeded 55\% only oncc: $55.2 \%$ voted in the 1972 presidential election. BUREAU OF THE CEnSUS, U.S. DePT. of Commerce, Statistical ABSTRACT of THE UNited STATES 243 (1987) [hereinafter STATISTICAL ABSTRACT OF THE U.S.]. The turnout in non-presidential federal elections over that same period was $38 \%$ or lower in every year but 1970 , when turnout was $43.5 \%$. Id. These data derive from census reports. $I d$. Slightly higher figures-showing presidential electoral turnouts between $53 \%$ and $55 \%$-are reported by the Federal Election Commission. See THE World AlmaNaC AND BooK of Facts 305 (1987).

Turnout is even lower in state elections. For example, a comparison of the total votes cast in the 1978 gubernatorial elections-which shared ballots with federal congressional elections-are uniformly lower across the states than turnouts in the 1980 presidential election. Compare Table 411, Statistical AbSTRact of The U. S., supra, at 238 with Table 399, id. at 231.

189. See D. MAGLEBY, DiRECT Legislation 98 (1984) (voter turnout in general elections is lower for ballot questions than for choosing candidates, although the reverse is true in primary elections).

This concern with low turnout in referenda is not new. See G. Perkinson, Remarks at Intercollegiate Debates of the Pentagonal Debating League of Southern State Universities 20 (Apr. 7, 1911), reprinted in BULLETIN OF THE UNIVERSITY OF TEXAS No. 16, June 8, 1911 (discussing non-participation in Oregon initiative elections).

190. See D. Magleby, supra note 189, at 77-99; J. Zimmerman, Participatory Democracy 4-6 (1986); Lee, California, in REFERENDUMS, supra note 51, at 108-09. 
leged members of society. The electorate is also skewed in the direction of older voters." 191 The electorate is skewed in partisan terms as well: In a typical election, relatively more registered Republicans vote than registered Democrats. ${ }^{192}$

The reapportionment decisions of the 1960 ' ${ }^{193}$ have provided some judicial guarantee of effective representation of majorities, but cannot guarantee the effective representation of any but those who vote. ${ }^{194}$ The same groups that have disproportionate influence on legislators because of their high rates of voter participation will likely have disproportionate influence in constitutional ratification elections. ${ }^{195}$ This identity of interest ${ }^{196}$ between the legislature and the electorate may lead to the adoption of proposals that favor groups who vote in disproportionately high numbers and disfavor other groups. These underrepresented groups include the "discrete and insular minorities" thought to be most needy of judicial and constitutional protection. ${ }^{197}$ Electoral ratification of constitutional proposals, then, guarantees only the sovereignty of the electorate, not the sovereignty of the people.

Some might deny that low voter participation is a significant problem. They could point to such evidence as Wolfinger's finding that, when

191. Lee, supra note 190, at 108-09.

192. Id. at 110 .

193. The Warren Court's reapportionment cases begin with Baker v. Carr, 369 U.S. 186 (1961) (federal cause of action under equal protection clause for malapportionment of state legislaturc), and Reynolds v. Sims, 377 U.S. 533 (1964) (one person-one vote standard).

194. Lee, supra note 190, at 109 \& n.39 (quoting W. Boyd of National Municipal League: "[S]ince the arrival of one man, one vote, state legislatures do not represent the entire population (not jnst those who vote) more accurately than the voters at any single election.") (emphasis and parenthesis in original); see also M. MeZEY, Comparative Legislatures 208 (1979) ("[l]egislators will be most likely to respond to the demands of a group if they see ... [a] direct connection between the group and their constituents and their election to the legislature"); J. ZimMERMAN, supra note 190, at 6 (concluding that underrepresentation of specific groups is due in part to low voter participation).

195. It has been observed that initiatives and referenda give disproportionate influence to social groups which vote in high numbers. See D. MAGLEBY, supra note 189, at 183-84. This observation has led one commentator to suggest that referenda may be no less democratic than legislative government despite the unrepresentative nature of the electorate. Lee, supra note 190, at 109 (quoting W. Boyd of the National Municipal League); see supra note 194.

196. This "identity of interest," of course, is the very function of representation. However, because the electorate is a distorted sample of the people as a whole, the electoral process can produce results that infringe the interests of groups which are not well represented in the political process. This, of course, is one of the intuitions behind Justice Stone's famous footnote four in United States v. Carolene Products Co., 304 U.S. 144, 152 n.4 (1937).

The difficult problem of malapportionment itself provides an instructive demonstration that a legislative body will often serve the interests of the narrow electorate even at the expense of the constitutional rights of others. See supra text accompanying notes 13-22; see also Baker v. Carr, 369 U.S. at 258-59 (Clark, J., concurring).

197. Carolene Products, 304 U.S. at 152 n.4 (1938). See generally J. CHOPER, supra note 158; J. ELY, supra note 158. 
transient residents are excluded, voting rates are relatively high. ${ }^{198}$ Yet Wolfinger himself documents very low turnout among some nontransient groups, and concludes that the electorate is a "distorted sample" of the people as a whole. ${ }^{199}$ Moreover, lower voting rates of transient residents cannot be dismissed as unimportant. ${ }^{200}$ Finally, the great wealth of evidence that electoral participation in America is much lower than in other democracies suggests that low voter participation is a significant problem. ${ }^{201}$

Others might argue that the appropriate response to low voter turnout is not to reduce the importance of voting by retaining procedures that reflect distrust of electoral ratification, but rather to reform electoral procedures to encourage greater participation. Governments could, for example, adopt compulsory voting, a device used in a number of western democracies as well as in some authoritarian regimes. ${ }^{202}$ Compulsory voting is fundamentally inconsistent with the individualism of American political culture, and it seems doubtful that Americans would accept such a plan. Still, there is no doubt that participation rises when voting is made compulsory. ${ }^{203}$ Reforming registration requirements to encourage voting would be less intrusive, although perhaps less successful as well. ${ }^{204}$ Even if voter participation were greater, however, other factors limit the ability of a single election to reflect the will of the people.

One of these is the problem of limited voter "capacity." This term is used here to denote the ability of a voter to make electoral choices that

198. R. WOLFINGER \& S. ROSENSTONE, WHO VOTES? $195-97$ (1980).

199. Id. at 108 .

200. I reject this conclusion because I believe that transient citizens are no less an element of the popular sovereign empowered to adopt constitutional principles than other citizens. It is also possible that transient citizens hold different values and policy preferences than do long-term residents of a particular community. Those different values ought to inform the process of constitution-making.

201. See sources cited supra notes 188-90; see also K. Phillips \& P. Blackman, Electoral Reform AND Voter Participation 23-34 (1975).

202. K. Phillips \& P. Blackman, supra note 201, at 33 \& n.7 (documenting compulsory voting in a number of countries including Australia, Austria, Belgium, Greece, Italy, Luxembourg, Spain, and Switzerland).

203. Id. at 34; J. Miller, Australian Government and Politics 86 (1954) (90\% turnout despite purely nominal enforcement of sanctions for non-voting).

204. See generally Rosenstone \& Wolfinger, The Effect of Registration Laws on Voter Turnout (September 1986) (unpublished manuscript available at the library of Boalt Hall School of Law); see also J. ZIMMERMAN, supra note 190, at 4 ("failure to register was responsible for 82 percent of those who did not vote"). But see K. Phillips \& P. BLACKMAN, supra note 201, at 7-22, 71-75 (arguing that neither increased participation nor increased political awareness is likely to result from procedural reform).

Rosenstone and Wolfinger performed a statistical analysis of a survey of more than 90,000 people in all $\mathbf{5 0}$ states and concluded that participation would rise by as much as $10 \%$ if registration restraints were removed. This amounted in 1976 to an additional 14 million voters. Rosenstone \& Wolfinger, supra, at 25. Importantly, the study found that black participation, at least in the South, is still disproportionately discouraged by registration laws. Id. at 9-13. 
may be considered rational in the sense that they consistently serve the voter's self-interest or promote her vision of the social good. ${ }^{205}$ There are several reasons to believe that many voters substantially lack the capacity to vote rationally; these include illiteracy, limited access to information, and deceptive campaign advertising.

Studies indicate that many voters cannot read even the bare text of some ballot questions. One study involving a Los Angeles ballot concluded that 60 to $75 \%$ of the voters could not read and understand the text of the questions. ${ }^{206}$

Beyond the mere capacity of voters to read the ballot is their ability to understand the issues involved. Modern constitutions are necessarily complex. While constitutional proposals drafted by the legislature or some other representative body might be more comprehensible than those prepared by the proponents of the initiative measures involved in many studies, ${ }^{207}$ even the fairest and most capable framer could not serve the needs of state governance without articulating coinplex ideas that voters may fail to comprehend. ${ }^{208}$

Ballot questions can be exceedingly complex. A recent California ballot, for instance, included proposals dealing with Acquired Immune

205. For a useful summary of the complex debate among political scientists regarding voter rationality, see P. NATCHEZ, IMAGES OF VOTING/Visions OF DEMOCRACY 183-210 (1985).

206. Note, The California Initiative Process: A Suggestion for Reform, 48 S. CAL. L. REv. 922, 935 n.67 (1975) [hereinafter Note, California Initiative Process] (citing AD Hoc CoMMITTEE ON Ballot Simplification, Report and Recommendations to the Los ANgeles City Council Governmental Efficiency Committee (1973)). The Note reports,

A reading analysis by the Loyola University Reading Center of three Los Angeles City propositions, three Los Angeles County propositions, and 22 state propositions (including nine initiatives) revealed that two ballot propositions were written at the 11 th-grade level, eight at the 13th-grade level, and 18 at the 16 th-grade level. ... It was estimated that $60-75$ percent of the voters could not read and fully understand the ballot measures as presented.... The reading experts advised ... [a Los Angles City Council committee] that Id. the reading level of Los Angeles voters was only that of the eighth grade.

207. Some contend that initiative measures are deliberately written in vague and complex terms. See, for example, Magleby's discussion of a California proposition written by landlords to limit rent control; the ballot title implied to some that a "yes" vote was in favor of rent control when, in fact, the reverse was true. D. MAGLEBY, supra note 189, at 143-44. See, also, Fischer, supra note 12, at 66 (1983) ("[b]allot propositions qualified by petition are not drafted in a way that inspires confidence in their care for and attentiveness to the problems they address. Written in secret by those who share a common view of societal problems, ballot propositions eschew compromise and tend toward extremism with appalling frequency").

Even amendments drafted by government officials may be written in opaque prose. An example is provided by the amendment at issue in Kohler v. Tugwell, 292 F. Supp. 978 (E.D. La.) (three judge court), aff'd per curiam, 393 U.S. 531 (1969). The amendment was presented by the legislature to allow the Mississippi River Bridge Authority to issue bonds to finance bridge construction. The trial court described the words of the amendment in this way: "At best ambiguous, they may in fact be unintelligible." 292 F. Supp. at 980.

208. Ballot complexity may even make it hard to know whether to vote "yes" or "no" to express a particular preference. Id. at 141; see also supra note 207. 
Deficiency Syndrome (AIDS), ${ }^{209}$ the control of toxins that cause cancer or birth defects, ${ }^{210}$ the pensions of state constitutional officers, ${ }^{211}$ the compensation of public employees, ${ }^{212}$ and the establishment of English as the state's official language. ${ }^{213}$ Prior issues have included the reforms of property taxes, ${ }^{214}$ campaign finances, ${ }^{215}$ and criminal justice. ${ }^{216}$ These proposals often run to hundreds of sections and subsections, ${ }^{217}$ and involve highly technical subjects with which most voters are unlikely to be familiar. ${ }^{218}$ This complexity increases both the likelihood of voter noncomprehension and the potential for voter manipulation by canipaign advertisers.

Handbooks distributed by the state nray help inform voters, ${ }^{219}$ but it is not clear how many read them. Most voters apparently obtain the

209. Proposition 64, AIDS Initiative Statute. See California Secretary of State, California Voters Pamphlet, 48-51 (General Election, Nov. 4, 1986).

210. Proposition 65, Restrictions on Toxic Discharges into Drinking Water; Requirement of Notice of Persons' Exposure to Toxics Initiative Statute. See California Secretary of STate, California Voters Pamphlet, 52-55, 62-63 (General Election, Nov. 4, 1986).

211. Proposition 57, Retirement Benefits for Nonjudicial and Nonlegislative Elected State Constitutional Officers. See California Secretary of State, California Voters Pamphlet, 20-23 (General Election, Nov. 4, 1986).

212. Proposition 61, Compensation of Public Officials, Employees, Individual Public Contractors Initiative Constitutional Amendment and Statute. See CaLIForNIA SECRETARY of State, California Voters Pamphlet, 36-39, 59-62 (General Election, Nov. 4, 1986).

213. Proposition 63, Official State Language Initiative Constitutional Amendment. See California Secretary of State, Calipornia Voters Pamphlet, $44-47$ (General Election, Nov. 4, 1986).

214. Proposition 13, Tax Limitation Initiative. See California Secretary of State, California Voters Pamphlet, 56-60 (Primary Election, June 6, 1978).

215. Proposition 9, Political Reform Initiative. See Calıfornia SeCRetary of State, California Voters Pamphlet, 34-37 (Primary Election, June 4, 1974).

216. Proposition 8, Criminal Justice Initiative Statutes and Constitutional Amendment. See California Secretary of State, California Voters Pamphlet, 32-35, 54-56 (Primary Election, June 8, 1982).

217. Proposition 18, a 1972 anti-obscenity measure, included 104 sections and subsections; Proposition 9, the Political Reform Act of 1974, included 11 chapters and 215 sections. Note, California Initiative Process, supra note 206, at 935 n.65.

218. For example, Proposition 65, the Toxic Waste Initiative of 1986, established levels of acceptable exposure to reproductive and carcinogenic toxins that were the subject of debate among scientists. L.A. Daily J., Oct. 30, 1986, at 4, col. 5.

219. Fischer, supra note 12, at 66 n.116; see also Grose v. Firestone, 422 So. $2 \mathrm{~d} 303,305$ (Fla. 1982) (discussion of ballot summaries and titles as aids to voter comprehension); Askew v. Firestone, 421 So. 2d 151, 156 (Fla. 1982) (defective ballot summary may be grounds for invalidating an initiative proposal). But see J. ZimMERMAN, supra note 190, at 75 \& n.38 (indicating that voters may not be able to comprehend the voter pamphlet because of the language used (citing $\mathrm{D}$. Magleby, Voter Pamphlets: Understanding Why Voters Don't Read Them (unpublished paper presented to the 1981 Annual Meeting of the American Political Science Association, New York, N.Y.))); D. MAGLEBY, supra note 189, at 136-39 (reviewing various assertions as to how many voters read handbooks). Magleby also reports that California handbooks raise the same "readability" problems as the ballot proposals themselves. Id. at 138-39. As to voter information about ballot issues generally, see $i d$. at $127-41$. 
bulk of their information from the mass media. ${ }^{220}$ While advertising campaigns may also provide important information, such information is often minimal or misleading. ${ }^{221}$ One indication that voters rely on limited information is the fact that most voters make up their minds on ballot questions on the eve of the election. ${ }^{222}$ This seems especially true of complex and technical proposals. ${ }^{223}$

In sum, the evidence collected in studies of voting behavior suggests that even those who do vote may be incapable of expressing informed and rational consent to constitutional change. Log-rolling, low levels of electoral participation, and limited voter capacity all suggest that the idealized view of electoral ratification as the voice of the popular sovereign is incorrect.

\section{Complex Revision Procedures May Better Reflect Popular Will}

The obvious rejoinder to the above critique of elections is that no better alternative exists. Concededly, elections are the only available means to discover the popular will. And, of course, the flaws in the electoral system discussed here apply equally to the electoral ratification of

220. D. MAGLEBY, supra note 189 , at $130-39$.

221. See, e.g., Fischer, supra note 12, at 66-67; Note, California Initiative Process, supra note 206, at 935 . For a discussion of the relationship of campaign financing to voter behavior, see $D$. MAGLEBY, supra note 189, at 146-59; Lee, supra note 190, at 101-07.

To demonstrate this point, it is worth quoting at length an account of how one initiative proponent achieved electoral success:

My next move was to place an initiative proposal on the ballot to give the bus and truck industry ... the right to pay 4 per cent tax in lieu of any and all other taxes. We had a fight with that one.

I tried to educate the voting public on the need for standard taxation for buses, pointing out that 1,700 small communities had no other public transportation besides buses. But the railroads wanted to crush the competition of the bus lines, and they campaigned against the initiative with propaganda and advertising. The measure was defeated by 70,000 votes.

Next time it was different.

I was going to beat the railroads at their own game. I convinced the bus owners to put up enough money for a first-class campaign. I hired a well-known cartoonist named Johnny Argens to draw a picture of a big, fat, ugly pig. Then I splashed that picture on billboards throughout the state with the slogan:

DRIVE THE HOG FROM THE ROAD!

VOTE YES ON PROPOSITION NUMBER 2

I also had millions of handbills printed with the same picture and message. During the last weeks of the campaign they were placed in automobiles in every city and town....

The campaign worked. Boy did it work! Nobody likes a roadhog, and the voters flocked to the polls and passed the constitutional amendment by $700,000 !$. .

All because the voters thought they were voting against roadhogs. That had nothing to do with it.

A. Shamish \& B. Thomas, The Secret Boss of California 37-38 (1971).

222. Lee, supra note 190 , at 110 (citing polling data collected during recent California electoral campaigns); see generally D. MAGLEBY, supra note 189, at 171. Magleby suggests that issues with which voters are familiar will not produce last-minute decisions. Id. at 170-73.

223. Lee, supra note 190, at 110; see also, D. MAGLEBY, supra note 189, at 170-71 (stating that public opinion is likely to be volatile on complex and technical proposals). 
all revisions, whether by textual or extratextual procedures. However, many textual revision procedures ${ }^{224}$ provide safeguards to ensure that revisions reflect broadly shared concerns rather than the self-interest of their authors.

Those who draft constitutions possess considerable power to include self-serving or imprudent provisions that the electorate would reject if presented for ratification individually. Because a constitution is presented as a whole, however, the voters may overlook offensive provisions and ratify the whole for the sake of its beneficial aspects. Even if we assume voters to be "rational maximizers" possessed of adequate information, they will weigh the costs and benefits of the new constitution and approve it if the net effect is beneficial, even if many provisions are detrimental. This results from the all-or-nothing nature of a ratification election. If voters lack competence, drafters have even more freedom to impose self-serving or imprudent constitutional provisions because voters will fail to understand the consequences of a revision.

The drafters also have the power to encourage log-rolling. By including provisions highly valued by particular factions of the electorate, the drafters can assure the adoption of the whole even though it contains provisions of no value to the majority of the people. Given that the electorate is not fully representative of the population at large, ${ }^{225}$ drafters could well propose a revision acceptable to a majority of the electorate but highly detrimental to the people as a whole.

Of course, this is not to suggest that all provisions of a constitution must be acceptable to all members of our diverse society. The problems discussed here arise inevitably from any proposal that addresses multiple subjects. The goal is not to eliminate tradeoffs-for that cannot be done-but to preclude opportunistic and exploitative drafting.

Because ratification elections are inadequate to reveal the popular will, other devices must be employed to ensure that constitutional change serves the interests of all the people. If constitutional framers are constrained so that their interests align with those of the people, the likelihood of exploitative revision will decline. Obviously, an exact congruence of interests is unlikely, unless revisions are adopted in a town meeting in which the drafter and the people are one and the same.

The constraints imposed on the constitutional drafter by typical revision provisions promote, at least to some extent, a unity of interest between the framers and the people. First, these provisions typically require electoral assent to the calling of a convention. ${ }^{226}$ This allows the

224. See supra text accompanying notes 23-38.

225. See supra text accompanying notes 190-92.

226. For a description of the revision procedures discussed in this paragraph, see supra text accompanying notes $23-38$. 
electorate to cut short a revision attempt if the risk of an undesired outcome outweighs its dissatisfaction with current constitutional arrangements. Second, constitutional conventions are elected by the voters. This promotes public discussion of the issues and creates an opportunity to select drafters who are representative of the people and unbiased by legislative office. Third, conventions must approve suggested changes individually before adopting the package as a whole. ${ }^{227}$ If this process takes place in public, as it often does, the public will be better able to scrutinize proposals and the possibility of revisions with unintended consequences may decline. The framers will also lose the opportunity to conceal self-serving provisions within the revision as a whole. Finally, the revision is presented to the electorate for ratification. The convention delegates may serve as opinion leaders on the proposal and thus enhance voter information and understanding.

Electoral ratification following this long process is less likely to produce irrational results. ${ }^{228}$ Of course, the electoral flaws noted above do not disappear, but they do pose fewer problems. Voters are better informed because of the duration and publicity of the process. ${ }^{229}$ The likelihood of revisions promoting narrow interests at the expense of broader concerns will decline because of the many opportunities for access to the revision process by the people generally and by representatives of adversely affected groups. ${ }^{230}$ Thus, complex revision procedures in conjunction with elections enhance the legitimacy of those elections by ensuring that the popular sentiments are accurately measured.

\section{B. Cumbersome Revision Procedures Promote Political Stability}

A revision could be adopted by two houses of the legislature and ratified at the polls within a few months. ${ }^{231}$ Thus, an important change

227. It is possible, of course, that log-rolling may occur within the convention. This is perhaps an inevitable consequence of drafting a complex revision proposal in a pluralist socicty. Nevertheless, this log-rolling is less problematic due to its greater visibility and to the other safeguards of the more complex revision process.

228. Cf. D. MAGLEBY, supra note 189, at 172-73 (suggesting that voter choice is more reliable in candidate elections than on propositions because of greater voter knowledge of candidates deriving from prior elections and from the primary-general clection sequence).

229. Cf. id. at $139-42$ (suggesting that voters are most likely to possess information about those propositions that are the subjects of advertising, campaign controversy, and media attention).

230. This "access" results from the opportunities provided by the more complex procedure to 1) campaign in the referendum on calling the convention, 2) to campaign in and run candidates in the election of delegates, 3) to participate in and to lobby the convention, and 4) and to campaign for or against the ratification of the convention's proposal.

231. This was the method used in Gatewood and Wheeler. See Gatewood v. Matthews, 403 S.W.2d 716, 717-18 (Ky. 1966); Wheeler v. Board of Trustees, $200 \mathrm{Ga} .323,326,37$ S.E.2d 322, 324 (1946). The Georgia constitution at issue in Wheeler was approved by the legislature on March 9, 1945, and promulgated just five months later on August 13, 1945. Proposed Amendment to the Constitution of 1877 approved March 9, 1945, tit. 1, no. 34, 1945 Ga. Laws 8; Wheeler, 200 Ga. at 
in a state's organic law could occur without sustained public attention and consideration. Unintended consequences are more likely to result from such speedy action than from more time consuming procedures that require greater electoral involvement and greater public awareness. In short, speed sacrifices deliberation. Expeditious revision procedures are ill advised because they undercut deliberation and stability and denigrate state constitutional law.

It seems obvious that constitutions that may be readily changed will in fact be changed more often than others. ${ }^{232}$ In states that allow constitutional initiatives, the state may alter its organic law in every general election. ${ }^{233}$ Some of these amendments involve the basic principles of government. California voters, for example, have in recent years adopted constitutional amendments protecting rights of privacy, ${ }^{234}$ limiting the discretion of the state courts in criminal justice jurisprudence, ${ }^{235}$ and establishing Enghish as the official language of the state. ${ }^{236}$ If constitutional change is both basic and frequent, constitutional law loses stability.

Stability in this sense is important. First, constant change makes effective political participation difficult by making it burdensome for citizens to inform themselves about pubhic affairs. Second, stability in constitutional law promotes the formation and maintenance of a social consensus on basic values. ${ }^{237}$ It does so by encouraging framers and courts to articulate basic values and to provide moral leadership for society. For example, the first amendment of the federal constitution and the

326, 37 S.E.2d at 324. Although the revision commission had been appointed two years earlier, the procedure allowed by the court could have lead to revision in a much shorter time.

232. The Florida Constitution, which is perhaps the most easily amended, was amended 41 times between its adoption in 1968 and the end of 1985, a rate of 2.4 amendments per year. THE COUNCIL OF STATE GOVERNMENTS, supra note 26, at 14 . The Kentucky Constitution, less readily changed, has been amended just 26 times between its 1891 adoption and the end of 1985, a rate of only .27 amendments per year. Id.

There is no doubt that the older procedures are more time consuming than the newer, simpler procedures. Compare the procedures established by FLA. CONST. art. XI, § 2, which allows an amendment to be placed on the next state ballot by the Revision Commission, with KY. CONST $\S 258$, which requires legislative action and at least two elections (three if the convention call requires electoral ratification of convention proposals). The first procedure requires a few months; the second, several years.

233. Or, as is true in California, in both general and primary elections. See Lee, supra note 190, at 109-10.

234. CAL. CoNST. art. I, $\S 1$, which was adopted in the November 1974 election, declares privacy an "inalienable right."

235. Proposition 8, supra note 216. Proposition 8 repealed statutes and revised a variety of constitutional provisions. See id.

236. CAL. CONST. art. III, $\S 6$ (added by initiative measure Nov. 4, 1986).

237. In a similar vein, Ronald Collins suggests that beeause state constitutional principles are not stable, state constitutional rights are not deemed "fundamental." Nat'l Law J., June 18, 1984, at 14 , col. 6 . 
decisions of the Supreme Court interpreting it arguably have done much to encourage tolerance of speech in American society. ${ }^{238}$ While counterexamples undoubtedly exist, ${ }^{239}$ stable constitutional law possesses at least the potential to promote a consensus on social values. Such a consensus contributes to social cooperation and peace. Given the cultural and social diversity of the American people, these concerns seem particularly important in American law.

Finally, frequent and easy change denigrates constitutional law. The federal constitution, infrequently amended, is a short document addressed primarily to the most basic values of our political society. ${ }^{240}$ Many state constitutions, on the other hand, are almost indistinguishable from statutory codes in their length, scope, and subject matter. ${ }^{241}$ The danger of including essentially statutory policies in a constitution is that the constitution will come to be viewed as little more than a statute. ${ }^{242}$ If the constitution addresses the same subjects as statutory law, and changes as frequently, it is less likely that constitutional principles will be regarded as having transcendant value. ${ }^{243}$ They may lose their capacity to inspire and maintain a social consensus.

\section{Cumbersome Revision Procedures Limit Majoritarianism}

The need to reconcile majority rule with minority rights has always been a central concern of American political thought. ${ }^{244}$ The federal and state constitutions contain many safeguards against the tyranny of the majority. ${ }^{245}$ These provisions would provide little protection for minor-

238. For another discussion of the relationship between first amendment jurisprudence and social attitudes toward speech, but which reaches a different conclusion, see L. BoLLINGER, THE TOLERANT SOCIETY 7 (1986).

239. It can be argued, for example, that the Supreme Court's abortion decisions beginning with Roe v. Wade, 410 U.S. 113 (1973), only served to accentuate debate and dissension by favoring one side of the conflict and by precluding compromise.

240. The federal constitution contains approximately 6700 words, see A. STURM, METHODS OF STATE CONSTITUTIONAL REFORM 9 (1954), and has been amended 26 times. The 26th amendment, lowering the age of suffrage to 18, was ratified in 1971. U.S. CoNST. amend. XXVI.

241. The shortest state constitution, that of Vermont, contains approximately 6600 words, while the longest, that of Alabama, contains approximately 174,000 words. THE Council of STATE GOVERNMENTS, supra note 26 , at 14 . State constitutions have addressed such subjects as the provision of free railroad transport, the teaching of home economics in public schools, and the definition of a "durable hard surface" for a public street. See Fellman, What Should a State Constitution Contain?, in Major Problems in State Constitutional Revision 137, 142 (W. Graves ed. 1960).

242. The California Constitution, for example, is to be found in many law libraries among the statutory codes of the state, between the Commercial Code and the Corporations Code.

243. This concern is strongest in states allowing both constitutional and statutory initiatives because voters may fail to distinguish between the two. In these states, proposals on similar subjects are likely to appear in both the constitution and the statutory code. When such is the case, it is difficult to maintain the perception of the constitution as a repository of transcendent principles.

244. See, e.g., The Federalist No. 10 (J. Madison).

245. See, e.g., U.S. Const. amends. I-X; CAL. CoNST. art. I. 
ity interests if they could be repealed readily by a popular majority. This may at least partly explain why constitutional protection of minorities has occurred primarily under the less easily amended federal constitution. The state constitutions may be less likely to limit majoritarianism simply because they are more readily changed by the majority. The argument that federal constitutional law is better able to protect minorities draws support from instances in which the U.S. Supreme Court has invalidated state constitutional proposals hostile to the rights of minorities on federal constitutional grounds. ${ }^{246}$

The protection of minorities from hostile electoral majorities acting through statutory initiatives and referenda is problematic, ${ }^{247}$ and seems especially troublesome where constitutional provisions are at stake. Examples of constitutional and other ballot proposals hostile to the rights of minorities abound. A recent example of a constitutional amendment perceived by many as an attack on minorities was the "English Only" initiative adopted by California voters in November $1986 .{ }^{248}$ Other examples include the attempted repeal of California's fair housing statute, ${ }^{249}$ attempts to pass exclusionary zoning measures, ${ }^{250}$ and attempts to quarantine those infected with the virus believed to cause AIDS. ${ }^{251}$

While more cumbersome procedures do not preclude the adoption of provisions hostile to minority interests, the deliberation and delay associated with these procedures should make the adoption of such provisions less likely. Delay will ensure the defeat of proposals that cannot retain majority support for a substantial period. Deliberation will give minority interests the opportunity to combat fear and prejudice with inforniation and education.

\section{CONCLUSION}

Those courts that have sanctioned attempts to revise state constitutions by extratextual procedures have perhaps done so in a belief that cumbersome textual procedures are unwieldy and obsolete. I believe they failed to consider adequately the rationale for these procedures. As

246. See Reitman v. Mulkey, 387 U.S. 369 (1967) (affirming state court's invalidation of initiative amendment preserving right to discriminate in housing, and holding the amendment violative of the fourteenth amendment to the federal constitution).

247. See, e.g., Gunn, Initiatives and Referendums: Direct Democracy and Minority Interests, 22 URB. L. ANN. 135 (1981).

248. CAL. CoNST. art. III, $\S 6$ (added by initiative measure Nov. 4, 1986).

249. See Reitman v. Mulkey, 387 U.S. 369 (1967); see also Hunter v. Erickson, 393 U.S. 385 (1969) (invalidating on fourteenth amendment grounds an initiative amendment to the Akron City Charter which would have repealed the city's fair housing ordinance).

250. See James v. Valtiera, 402 U.S. 137 (1971) (upholding California statute forbidding state to fund public housing projects that had not been approved by a referendum in the community).

251. Proposition 64, supra note 209. 
I have argued above, the typically more complex textual procedures enhance the capacity of elections to measure the will of the people, both by promoting voter competence and by limiting the danger of self-interested drafting.

The recent trend toward allowing constitutional change more readily, by permitting extratextual revision or by establishing simple and expedient procedures for change, threatens basic values of American constitutionalism. I have argued that the older, more complex procedures better promote popular sovereignty, political stability, pluralism, and limited constitutional government.

Michael G. Colantuono*

* B.A. 1983, Harvard University; third-year student, Boalt Hall School of Law, University of California, Berkeley. 